\title{
The Interdependent Coexistence of the Rational Civilizations: The Mental Origin of Civilizations
}

\author{
Dingyu Chung \\ Utica, MI, USA \\ Email: dy_chung@yahoo.com
}

How to cite this paper: Chung, D.Y. (2020) The Interdependent Coexistence of the Rational Civilizations: The Mental Origin of Civilizations. Journal of Behavioral and Brain Science, 10, 46-94. https://doi.org/10.4236/jbbs.2020.101004

Received: December 1, 2019

Accepted: January 14, 2020

Published: January 17, 2020

Copyright $\odot 2020$ by author(s) and Scientific Research Publishing Inc. This work is licensed under the Creative Commons Attribution International License (CC BY 4.0).

http://creativecommons.org/licenses/by/4.0/

(c) (i) Open Access

\begin{abstract}
The paper purposes that the three major civilizations are territorial rational civilization originated from the tribes before the Axial Age, discrete Western rational civilization originated from the mega empires in Middle East and Greece during the Axial Age, and the connective Eastern rational civilization originated from the mega empires in India and China during the Axial Age. Territorial rational civilization with territorial worldview for ingroup and outgroup individuals produces territorial nationalist democracy based on rule of boundary to deal with ingroup and outgroup individuals. Discrete Western rational civilization with discrete worldview for discrete and independent individuals produces discrete liberty-equality democracy based on rule of law to deal with discrete individuals. Connective Eastern rational civilization with connective worldview for connective and related individuals produces connective common wellbeing democracy based on rule of relation to deal with connective individuals. The current highly international interdependence produces the purposed internationalized interdependent community which allows the interdependent coexistence of the three rational civilizations by establishing the promotion of rational civilizations, the basic rules of relation and law, the potential civilizational and the regional defense boundaries, and the cooperation in international relations. The mental origin of the rational civilization consists of the social brain for instinctive intragroup relations and worldviews to form the original human social group, the mental immune system for instinctive mental therapy, theory of imaginary mind for imaginary religious and political entities with their own minds to form cohesive large social groups, and the thinking brain for rule to form rational civilization.
\end{abstract}

\section{Keywords}

Civilization, Mental Origin of Civilizations, Interdependent Coexistence, Tribalization, Globalization, Internationalization, Civilizational Boundary 


\section{Introduction}

Civilization comes from the Latin word civis which means someone who lives in a town. The most important characteristics of civilization include urban society, centralized government, organized religion, job specialization and social classes, highly developed art, advanced technology and infrastructure, and writing. The four major early civilizations are Lower Mesopotamia civilization between Tigris and Euphrates Rivers (3000 BCE), Egyptian civilization along the Nile River (3000 BCE), the Harappan civilization in the Indus River Valley (in present-day India and Pakistan; 2500 BCE), and Chinese civilization along the Yellow and Yangtze Rivers (2200 BCE) as the longest continuous history of any country in the world with 3500 years of written history.

Since the Industrial Revolution, the Western civilization certainly has become the most powerful and affluent civilization in the world, and appears to be most likely the ultimate universal civilization. In the article "the Universal Civilization" [1] [2] by V. S. Naipaul who won the 2001 Nobel Prize in literature, the pursuit of happiness is at the heart of the attractiveness of the universal civilization. It cannot generate fanaticism. But it is known to exist; and because of that, other more rigid systems in the end blow away. Naipaul offered himself as proof of the universal civilization. He was born in British colonial Trinidad to an Indian family, and his grandfather worked the sugar plantations as indentured laborers. Naipaul moved from the periphery to the center by educating and living in England and becoming a literary icon which was impossible to do outside of the universal civilization.

According to the book "The Clash of Civilizations and the Remaking of World Order" (1996) [3], political scientist Samuel Huntington proposed that in the twenty first century in the post-Cold War world, a clash of civilizations would replace the clashes among nation-states in the nineteenth century and among ideologies in the twentieth century. According to Huntington, the West, and especially the United States, which has always been a missionary nation, believe that the non-Western peoples should commit themselves to the Western values of democracy, free markets, limited government, human rights, individualism, rule of law, and should embody these values in their institutions.

Since the end of the Cold War in early 1990s, liberal democracy has become a major political system as described in "The End of History" [4] by political scientist Francis Fukuyama who claimed that the human history was ended with liberal democracy and private free market economy. Sociologist Salvatore Babones began to use the historical Chinese concept of tianxia ("all under heaven") to describe the structure of the millennial world-system as an American Tianxia that has endogenized the entire world-economy under a single, American-dominated political system [5]. Liberal individualism has become the leitmotif of an emerging order in which people of all nationalities seek a share in the economic, cultural, and political system that is America writ large.

Ever since the first Industrial Revolution, industrialization has impacted in 
globalizations. In particular, advances in transport and telecommunications have had a huge impact in globalization. In economy, with increasing trade and communication, more and more international corporations are extending their reach across land and sea. Mega international corporations become the main driving force for globalization. To a mega international corporation, globalization is often offered as the strategic effort to treat the world as a single market in which to do business, a single research and development laboratory, a single production center, a single logistics network, and a single headquarters site [6]. A mega international corporation has no national boundary among nations. The result is the globalized integrated community based on rule of integration which is established by the World Bank (WB), International Monetary Fund (IMF), and World Trade Organization (WTO) as described by Herman Daly [7]. Such rule of integration is based on liberal democracy and free market established by advanced industrial countries, such as America and the West European countries. Under the globalized integrated community, national boundary is basically open, and the purpose of globalization is to maximize the efficiency of international corporations and the global economic growth as described by Economist Jagdish Bhagwati [8]. To some countries, globalization includes economic, political, and military globalizations.

However, liberal democracy has not dominated the world. According to the Democracy Index by the Economist Intelligence Unit (the world's leading resource for economic and business research) [9], in 2018, only 20 countries (4.5\% of the world population) are "full democracies", 55 (43.2\%) are "flawed democracies", 39 (16.7\%) are "hybrid regimes (illiberal democracy)", and 53 (35.6\%) are "authoritarian regimes". The 2017 Democracy index registered the worst year for global democracy since 2010-11 in the aftermath of the global economic and financial crisis. In 2016, the United States was downgraded from a full democracy to a flawed democracy.

The problem with the globalized integrated community based on the dominant Western civilization is that different countries have different civilizations as described in "Culture and point of view" by Richard E. Nisbett and Takahiko Masuda [10]. In the West, the point of view (perspective) is discrete, and the world consists of discrete and independent individuals, while in the East, the point of view is connective, and the world consists of connective and related individuals. The Western civilization has discrete worldview, and the Eastern civilization has connective worldview. The Western-style independent and largely discrete self is hard for East Asians to comprehend. Philosopher Hu Shih states, "in the Confucian human-centered philosophy man cannot exist alone; all action must be in the form of interaction between man and man" [11]. For East Asians, the person is so connected to others that the self is literally dependent on the context. As philosopher Donald Munro put it, East Asians understand themselves "in terms of their relation to the whole, such as the family, society, Tao Principle, or Pure Consciousness" [12]. The Westerners pay attention to the focal object separated from its surrounding based on discrete perception, while the 
Easterners attend more broadly to the overall surroundings and to the relations between the object and the field [13] [14]. One typical way to identify the East vs the West is to pair panda, monkey, and banana. Typically, the Westerners pair panda and monkey for the same category (animals), while the Easterners pair monkey and banana for the relationship (monkey eats banana).

The different worldviews in the West and the East produce different religions and politics. In the West originated from the Middle East and Greece, the major religions (Judaism, Christianity, and Islam) are highly discrete and competitive in believing that only one religion is the eternal religion, and in their sacred prophecies, all other religions will be punished severely and perished at the end of the normal civilization. In the East, the major religions (Hinduism, Buddhism, Confucianism, and Daoism) are connected and coexist peacefully without the prophecy of end time. Chinese politics with the Eastern civilization based on collective wellbeing and cooperation is different from the Western liberal democracy based on discrete individualism and partisan competition.

Another civilization is territorial civilization with territorial worldview based on rigid boundary between ingroup and outgroup. Basically, the three major civilizations in the world are territorial rational civilization with territorial worldview originated from the tribes before the Axial Age with rigid boundary, discrete Western rational civilization with discrete worldview originated from the mega empires in the Middle East and Greece during the Axial Age with flexible boundary, and connective Eastern rational civilization with connective worldview originated from the mega empires in India and China during the Axial Age with flexible boundary from about the 8th to the 3rd century BCE [15]. The three rational civilizations derived from the thinking brain have different rational rules. Territorial rational civilization has rule of boundary to deal with basically good ingroup individuals and basically bad outgroup individuals, and produces territorial nationalist democracy. Discrete rational civilization has rule of law to deal with all basically discrete bad individuals, and produces discrete liberty-equality democracy. Connective rational civilization has rule of relation to deal all basically connective good individuals, and produces connective common wellbeing democracy. The globalized integrated community with integrated worldview originated from WB, IMF, and WTO with open boundary has rule of integration to deal with basically open individuals.

As a result, the globalized integrated community is futile as it simply cannot integrate all three different civilizations under rule of integration. Futile globalization is described by Sociologist Koert Debeuf in "Tribalization: Why war is coming" [16], which describes that the end of globalization is tribalization which brings chaos and poverty. The alternative to globalization is internationalization as proposed by Sociologist Herman Daly [7] [17]. According to Herman Daly, globalization, considered by many to be the inevitable wave of the future, is frequently confused with internationalization, but is in fact something totally different. Internationalization refers to the increasing importance of relations between nations: international trade, international treaties, alliances, protocols, etc. 
Globalization refers to global economic integration of many formerly national economies into one global economy. Derived from internationalization, the internationalized interdependent community has interdependent worldview based on rule of interdependence for division of labor among the three different civilizations, and has varied boundary. The development of the internationalized interdependent community requires the New Axial Age. The three local civilizations and the two world communities are shown in Table 3. The internationalized interdependent community provides the interdependent coexistence of the ration civilization. In fact, the interdependent coexistence of connective and discrete rational civilizations already exists in "Chimerica" to describe the symbiotic relationship between China and the United States according to Niall Ferguson [18]. Chimerica has enhanced the global economic growth, and the trade war in Chimerica has been hurting the global economic growth.

All different civilizations have the same mental origin as we are all humans. The paper proposes that the mental origin of the rational civilization consists of the social brain for instinctive intragroup relations and worldviews to form the original human social group, the mental immune system for instinctive mental therapy, theory of imaginary mind for imaginary religious and political entities with their own minds to form cohesive large civilized groups, and the thinking brain for rule to form rational civilization as Table 1.

Section 2 describes the mental origin of civilizations. Section 3 deals with the mega empires and worldviews. Section 4 describes the Axial Age and social orders. Section 5 explains the Industrial Revolution and democracies. Section 6 deals with globalization and tribalization. Section 7 describes internationalization and interdependent coexistence of the rational civilizations.

\section{The Mental Origin of Civilizations}

The mental origin of rational civilization explains all mental capacities to develop rational civilization. The paper proposes that the mental origin of rational civilization consists of the social brain for instinctive intragroup relations and worldviews (intergroup relations) to form the original small human social group,

Table 1. The mental origin of the universal civilization.

\begin{tabular}{|c|c|c|}
\hline Mental origin & Components & function \\
\hline the social brain & $\begin{array}{l}\text { instinctive intragroup relations } \\
\text { and worldviews }\end{array}$ & $\begin{array}{l}\text { to form the original small } \\
\text { human social structure }\end{array}$ \\
\hline $\begin{array}{l}\text { the mental } \\
\text { immune system }\end{array}$ & $\begin{array}{l}\text { instinctive comforter against } \\
\text { hardship, hyperactivity against } \\
\text { danger, and phobia against } \\
\text { unfamiliarity-uncertainty }\end{array}$ & $\begin{array}{l}\text { for instinctive } \\
\text { mental therapy }\end{array}$ \\
\hline theory of imaginary mind & $\begin{array}{l}\text { imaginary religious and political } \\
\text { entities with their own minds }\end{array}$ & $\begin{array}{l}\text { to form cohesive } \\
\text { large social groups }\end{array}$ \\
\hline thinking brain & rationalism and empiricism & $\begin{array}{l}\text { to form rational large civilized } \\
\text { group }\end{array}$ \\
\hline
\end{tabular}


the mental immune system for instinctive mental therapy, theory of imaginary mind for imaginary religious and political entities with their own minds to form cohesive large social group, and the thinking brain for rational rule to form rational civilization as Table 1 .

\subsection{The Social Brain}

The social brain [19] [20] [21] [22] is the network of brain regions that are involved in understanding others. We are biologically hard-wired for interacting with others. The social brain is located mainly in the neocortex in the outmost layer of the brain. The neocortex is much larger in humans as compared to other primates and mammals of similar size. The social brain also involves the neurotransmitter/hormone system to provide a psychopharmacological platform for the cognitive component.

The social brain contains instinctive relations to form the default social structure. All social animals have instinctive relations to form the default social structures without training or with little training. The human social brain [23] consists of instinctive intragroup relations and instinctive worldviews. The social brain for instinctive intragroup relations and worldviews is to form the original small human social group.

\subsubsection{The Intragroup Relations}

In the human social brain, intragroup relations consist of family, alliance, division of labor, and multigeneration relations The four intragroup relations to protect social members are family intragroup relation to protect vulnerable children through commitment, alliance intragroup relation to protect vulnerable individuals through reciprocity, division of labor intragroup relation from interdependent specialists to protect vulnerable pregnant females through interdependence, and multigeneration intragroup relation from older leaders-mentors to protect next generation through generativity (legacy).

Family intragroup relation benefits vulnerable children against neglect by forming kinship group [24] whose relations depend on commitment to a social group rather than reciprocal benefit of individuals. The origin of collectivistic intragroup relation is the social group of caregivers and vulnerable children. For non-primate vertebrates, the brain size for family intragroup relation is proportional to the duration and complexity of commitment [25]. The neurotransmitter to promote family intragroup relation is oxytocin, so people feel good when they are with their kin.

Alliance intragroup relation benefits vulnerable individuals against predation by forming an alliance group [20] [21] [22] whose relations depend on reciprocal benefit of individuals rather than commitment to a social group. The base of alliance intragroup relation is extensive and complex socialization. For primates, the brain size for alliance intragroup relation is proportional to the group size and the complexity of socialization. According to Dunbar, the proper group size based on the human brain size is around 150 [26]. The neurotransmitter to 
promote alliance intragroup relation is endorphins, so people feel good when they have friends.

Division of labor intragroup relation benefits vulnerable specialists against handicaps by forming a specialist group from specialists whose relations depend on existential interdependence [27] [28]. The early hominins formed the interdependent specialist groups consisting of the forest group of homemaker-forager for women and children and the woodland group of explorer-forager for men in the mixed forest-woodland habitat. The handicap was the feet which were still suitable for climbing trees, and not suitable to walk long distance and run fast on the ground especially for pregnant women and small children in woodland area. Later, the division of labor became gatherer-hunter in open savanna habitat. This division of labor intragroup relation is called eusociality [29] characterized by the division of labor as in eusocial bees and ants. Homo sapiens are also eusocial [27]. Division of labor requires mind-reading mentalization [30].

Multigeneration intragroup relation benefits future generations by forming multigeneration group whose relations depend on generativity [31] [32] [33] [34]. Unlike great apes, infertile women have long life after menopause allows multiple generations to live together. The caring of infertile women after menopause for their grandchildren and great-grandchildren is the base of legacy. Therefore, the four intragroup relations are family intragroup relation to benefit vulnerable children through commitment, alliance intragroup relation from allies to benefit vulnerable individuals through reciprocity, division of labor intragroup relation from specialists to benefit vulnerable specialists through interdependence, and multigeneration intragroup relation from multiple generations to benefit vulnerable future generations through generativity. These instinctive intragroup relations produce the default social structure with family group, alliance group, division of labor, and generational assistance.

\subsubsection{Worldviews}

For social animals, instinctive worldview (intergroup relation) is derived from ingroup and outgroup. In ingroup, individuals share similar interests and attitudes, and produce instinctive feeling of ingroup favoritism as solidarity, community, and exclusivity [35]. Individuals in outgroup outside one's own group are different in interests and attitudes, and produce instinctive feeling of outgroup derogation as inferiority and alienation. Morality is defined as proper behavior. Morality toward ingroup is opposite of morality toward outgroup [36]. Ingroup morality is cooperative connection derived from instinctive ingroup favoritism. Outgroup morality is zero-sum aggressive competition derived from mutual outgroup derogation among social groups. According to evolutionary psychologists, this discrimination between connective ingroup morality and competitive outgroup morality has evolved because it enhances group survival in terms of instinctive cooperative connection toward ingroup and instinctive aggressive competition toward outgroup [37].

Such attitudes toward ingroup and outgroup are instinctive, appearing even in 
babies at few months old. As shown in the Infant Cognition Center at Yale University [38], babies prefer the objects (such as dolls) as ingroup objects that have similarities with the babies rather than the objects as outgroup objects that do not have similarities with the babies. Babies also prefer the objects with helpful behavior to the objects with bully behavior. However, babies prefer the doll that bullies another doll that is not like the babies. In other words, even though babies dislike the individuals who harm other individuals, babies prefer the individuals who harm outgroup individuals that are not like the babies. The zero-sum competitive attitude toward outgroup is instinctive. On the basic level, the relation toward outgroup is discrete without connection, while the relation toward ingroup is connective with connection.

This bimodal ingroup and outgroup relate to the bimodal proactive aggression and reactive aggression, respectively [39]. Proactive aggression generally results from the conflict toward ingroup, while reactive aggression generally comes from the conflict toward outgroup [40]. The distinction between the two types is centered on the aims of aggression. Proactive aggression aiming at outgroup involves a purposeful planned attack with an external or internal reward as a goal. It is characterized by attention to a consistent target, and often by a lack of emotional arousal. By contrast, reactive aggression aiming at ingroup is a response to a threat or frustrating event, with the goal being only to remove the provoking stimulus. Proactive aggression toward outgroup is characterized by low physiological arousal, a lack of social communication, and targeting of vulnerable body parts, because outgroup is basically a discrete group without any connection to the aggressor. By contrast, reactive aggression toward ingroup is associated with high physiological arousal and communication of intent including threats, because ingroup is basically a connective group with connection with the aggressor. The two types are sometimes easy to distinguish. For example, when two animals compete with steadily escalating intensity, as frequently occurs in fights over food or mates, aggression is typically reactive without any proactive elements.

Tulogdi et al. [41] found that proactive aggression was associated with innervation of the central and basolateral amygdala, the lateral hypothalamus, and the ventrolateral periaqueductal gray. By contrast, reactive aggression was associated with the medial amygdala, the mediobasal hypothalamus, and the dorsal periaqueductal gray [42]. The results of Tulogdi et al. indicate the existence of two different pathways in a key neural circuit underlying aggression.

Worldviews include territorial worldview for ingroup-outgroup with a rigid boundary between ingroup and outgroup, discrete worldview for extended outgroup without a rigid boundary between ingroup and outgroup, and connective worldview for extended ingroup without a rigid boundary between ingroup and outgroup. Humans with fairly distinctive boundary in the original human society were evolved with territorial worldview which has a high propensity for proactive aggression toward outgroup and a low propensity for reactive aggression toward ingroup. 
On the other hand, chimpanzee and bonobo have fission-fusion society with overlapping social groups in which the social group size and composition change throughout the year with different activities and situations. As a result they do not have rigid boundary between ingroup and outgroup. The natural habitats of chimpanzees and bonobos are separated by Congo River. The poor natural habitat where chimpanzees live has much higher resource competition than the rich natural habitat where bonobos live. Therefore, the principal worldviews of chimpanzees and bonobos are discrete worldview adaptive to competition and connective worldview adaptive to cooperation, respectively. Discrete worldview in chimpanzee is shown in a high propensity for proactive aggression and reactive aggression, while connective worldview in bonobo is shown in a low propensity for proactive aggression and reactive aggression. Compared with chimpanzees and bonobos, humans have a high propensity for proactive aggression like chimpanzees and unlike bonobos, and a low propensity for reactive aggression unlike chimpanzees and like bonobos [39]. In bonobos, no proactive aggression leading to intergroup killings has been observed [43]. Proactive aggression toward conspecifics is accordingly much more common in chimpanzees and humans than in bonobos, where it is infrequent or absent. The highly aggressive behaviors of adult male chimpanzees can be described as male warriors [44]. Because of division of labor intragroup relation based on interdependence in humans, chimpanzees and bonobos without division of labor intragroup relation both show more reactive aggression toward ingroup than humans. The human low propensity for reactive aggression toward ingroup is shown in human small canine teeth unlike large canine teeth in other animals for ingroup fighting. The two important traits that distinguish early hominins from other apes are bipedalism and small canine teeth [28].

\subsection{The Mental Immune System}

The immune system is a network of cells, tissues, and organs that work together to provide countermeasures against harmful invaders (pathogens). Different immune subsystems provide different countermeasures against different harmful invaders. The balanced immune system has the immune system regulators to balance the activities of the immune system. As the highly imbalanced immune system without the proper immune system regulators, the overactive immune system causes allergies and auto immune diseases as physical disorders against ubiquitous harmful and harmless detected invaders.

In the same way, in the mental immune system [23], the different mental immune subsystems provide the different countermeasures against different adversities. The balanced mental immune system has the mental immune system regulators to balance the activities of the mental immune system. As the highly imbalanced mental immune system without the proper mental immune system regulators, the overactive mental immune system causes mental allergies and auto immune diseases as personality-mental disorders [45] against ubiquitous harmful and harmless perceived adversities. 
The instinctive mental countermeasures in the mental immune system include comforter against hardship, hyperactivity against danger, and phobia against unfamiliarity-uncertainty. Each countermeasure has its regulator to avoid excess countermeasure. The excessive countermeasure without balancing by the regulator leads to the personality disorder. The mental immune system is instinctive, because it is mediated by neurotransmitters as in Table 2 .

Religions, particularly the Abrahamic religions (Judaism, Christianity, and Islam), intertwine closely with the mental immune system. As a result, religions that involve the mental immune system are important for the mental health of believers. In the Abrahamic religions (Judaism, Christianity, and Islam), God is assumed implicitly or explicitly as heavenly parent, while the believers are God's children. In the Abrahamic religions, the mental immune system of adult believers relies on heavenly parent as that the mental immune system of dependent children relies on parents. To dependent child, committed parents are the love against hardship, the protector against danger, and the authority against unfamiliarity-uncertainty. To the adult believers in the Abrahamic religions, heavenly parent provides the protection against danger, the love against hardship, and the authority against unfamiliarity-uncertainty. The heavenly maternal-like love is the religious comforter as the countermeasure against hardship. For the Abrahamic religions, God is love. The heavenly parental protection in the form of miraculous salvation is the religious hyperactivity as the countermeasure against danger. For Judaism, the confirmation for the miraculous salvation is the miraculous salvation of Israelites from oppression and the deliverance into the Promised Land. For Christianity, the confirmation is the miraculous salvation through Jesus' sacrifice and resurrection. For Islam, the confirmation is the miraculous salvation of Mecca to herald the advent of the Prophet Muhammad. The Abrahamic religions celebrate the miraculous salvations every year. The heavenly paternal-like authority in power, laws, and traditions provides the phobia against moving to unfamiliar-uncertain way of life (sins). The authority is expressed as righteousness. For the Abrahamic religions, the heavenly authority (righteousness) is written in the sacred scriptures. Whenever the believers face adversities, the believers seek relentlessly for the heavenly love against hardship, the heavenly miraculous salvation against danger, and the heavenly authority against unfamiliarity-uncertainty.

Table 2. The instinctive mental immune system.

\begin{tabular}{|c|c|c|c|c|c|}
\hline Countermeasure & Adversity & Purpose & $\begin{array}{l}\text { Countermeasure } \\
\text { neurotransmitter }\end{array}$ & Regulator & Personality disorder \\
\hline comforter & hardship & $\begin{array}{l}\text { maintain } \\
\text { durability }\end{array}$ & endorphins & dopamine antagonist & $\begin{array}{l}\text { odd-eccentric } \\
\text { cluster }\end{array}$ \\
\hline hyperactivity & danger & $\begin{array}{l}\text { maintain } \\
\text { existence }\end{array}$ & adrenaline & serotonin agonist & $\begin{array}{c}\text { dramatic-impulsive } \\
\text { cluster }\end{array}$ \\
\hline phobia & unfamiliarity-uncertainty & $\begin{array}{l}\text { maintain } \\
\text { tradition }\end{array}$ & adrenaline-glutamate & $\begin{array}{l}\text { serotonin-GABA } \\
\text { agonist }\end{array}$ & $\begin{array}{l}\text { fearful-anxious } \\
\text { cluster }\end{array}$ \\
\hline
\end{tabular}


As for small children, the religious immune system in the Abrahamic religions started with the unregulated immune system without any delayed gratification. The impatient believers want the religious countermeasures at once. There are many stories about such unregulated religious countermeasures in the Abrahamic religions. For examples, in the long journey from Egypt to the Promise Land, Israelites frequently complained, and wanted immediate miraculous salvation without delay as what infants normally do. Inevitably, God taught Israelites to wait for the right time with delayed gratification. God the heavenly parent introduced the heavenly providence (wisdom) as the religious regulator to regulate the religious immune system. The heavenly providence prevents overactive religious countermeasure against ubiquitous perceived adversity as in personality-mental disorders. Believing in the heavenly providence, a believer in the heavenly love looks beyond prevailing hardship to the coming of the heavenly love, resulting in the elimination of the overactive religious comforter against ubiquitous perceived hardship. Believing in the heavenly providence, a believer in the heavenly miraculous salvation looks beyond prevailing danger to the coming of the divine salvation, resulting in the elimination of the overactive religious hyperactivity against ubiquitous perceived danger. Believing in the heavenly providence, a believer in the heavenly authority looks beyond prevailing unfamiliarity-uncertainty (sins) to the coming of the heavenly authority, resulting in the elimination of the overactive religious phobia against ubiquitous perceived unfamiliarity-uncertainty. Essentially, the Abrahamic religions follow the natural regulated immune system for children. The religious mental immune system is for the Abrahamic religions.

For Buddhism, the way to deal with the sufferings from social disorders and personality mental disorders is through the Eightfold Path consisting of right view, right aspiration, right speech, right action, right livelihood, right effort, right mindfulness, and right concentration. The sufferings from the social disorders can be minimized with right view, right aspiration, right speech, right action, right livelihood, and right effort in the Eightfold Path. The sufferings from the personality/mental disorders can be minimized with right mindfulness (mindfulness meditation) and right concentration (concentration meditation). The emotion regulation from meditation [46] has been investigated to show the decreases in emotional interference by unpleasant stimuli and in the time to return to emotional baseline after stress. The emotional regulation relates to the strengthening of prefrontal cognitive control mechanisms by meditations.

For Confucianism, the way to deal with emotional problem is the middle way (mean) to maintain balance. In the first chapter of the Doctrine of Mean from Confucianism describes how to maintain mental balance. "When joy, anger, sorrow and pleasure have not yet arisen, it is the state of equilibrium. When they arise to their appropriate levels, it is the state of harmony. The state of equilibrium is the great base of all-under heaven. The state of harmony is the universal path to be pursued. When the states of equilibrium and harmony are actualized, Heaven and Earth are in their proper positions, and all things are nourished". 
The goal of the balance in the balanced mental immune system is to reach the state of equilibrium without arising emotion and the state of harmony with arising emotion to balance adversity-fortune. Whenever one thinks too much about adversity, think about possible fortune after adversity. Equally, whenever one thinks too much about fortune, thinks about possible adversity after fortune. Such thinking helps to nurture the normal instinctive mental system which is regulated to maintain balance. The middle way to maintain balance enhances the instinctive regulators in the mental immune system.

\subsection{Theory of Imaginary Mind}

All supernatural entities and large social groups entities such as nation-states are derived from theory of imaginary mind where a person attribute mental states of mind (beliefs, intents, desires, emotions, knowledge, etc.) to imaginary others (supernatural deities and nation-states), and understand that imaginary others have beliefs, desires, intentions, and perspectives that are different from the person. Theory of imaginary mind is derived from theory of real mind as the original theory of mind where a person attributes mental state of mind to the others as real people, not imaginary entities. No other animals have such robust theory of mind, so other animals do not have religions and nation-states. As shown in the previous paper [47], theory of mind was not evolved originally to accommodate religious behaviors. Theory of mind was evolved originally to accommodate interdependent division of labor between the forest specialist group (women and children) and the woodland specialist group (men) in early hominins who lived the mixed forest-woodland habitat. To complement each other's work without interfering each other's work, one specialist group had to recognize that the other specialist group existed to think for themselves and to do different works. The result was theory of mind which is to recognize that the others exist to think for themselves (The forest-woodland groups became the hunter-gatherer groups for the Homo species in the savanna habitat). Under normal condition, specialists in division of labor were real.

Humans under existential pressure invented theory of imaginary mind for imaginary specialists as imaginary agents who existed to think for themselves and to do different work in imaginary division of labor to enhance survival chance, resulting in the religious relief of stress and anxiety to enhance the survival chance of individuals [23]. Under existential pressure, such theistic imagination can also be the religious enforcement of social bonds to enhance the survival chance of social group [48] [49]. Robust religion is unique to humans, because robust theory of mind is unique to humans [50]. According to Maurice Bloch [51], the first widespread human religion was derived from the imagination to produce imaginary female figurines and imaginary cave paintings to helps them to survive under existential pressure at the time of the Upper Paleolithic Revolution.

According to a PET study, theory of mind activates the medial prefrontal node to handle the mental state of the self, the superior temporal sulcus to detect the behavior of other animals and analyzes the goals and outcomes of this beha- 
vior, and the inferior frontal region to maintain representations of actions and goals [52]. According to Kapogiannis and Deshpande in the functional MRI study of the brains of both self-declared religious and non-religious individuals, individuals with stronger theory of mind activity were found to be more religious [53]. Thinking about God activates brain regions associated with theory of mind [54]. Autistic individuals with problems in imaginative capacities and pretend plays are incapable of theory of mind [55] [56] [57]. Autism with the deficits in theory of mind is linked to lower belief in God [58].

Up to two-thirds of the children who have the ability for theory of mind between the ages of 3 and 8 have imaginary companions [59]. They need imaginary companions to provide comfort in times of stress, boredom, and loneliness, to help them make sense of the adult world, and to overcome traumatic experiences. Taylor feel imaginary companions are common among children and are part of normal social-cognitive development [60]. For adults, such childhood imaginary companions are replaced by adulthood imaginary guardians who intertwine closely with the real social brain and the real mental immune system. As a result, to believers, such imaginary guardians become real supernatural guardians to maintain cohesive large social group and to uphold believers' mental health. Large social groups and believers cannot survive well without adulthood imaginary guardians.

\subsection{The Thinking Brain}

The brain includes the emotional-instinctive brain, the subjective thinking brain, and the objective thinking brain [61]. The emotional-instinctive brain locates in the subcortex and the limbic regions, and the neurotransmitters include endorphins for individualistic intragroup relation and oxytocin for collectivistic intragroup relation. Emotion and instinct are blunt and black-and-white reactions without discerning. They occur extremely rapidly before conscious thoughts. The subjective thinking brain uses reasoning to defend the view derived from instinct and emotion against the opposite point of view. The subjective thinking brain locates in the orbital frontal cortex for the processing of emotions, the anterior cingulate for conflict resolution, the posterior cingulate for making judgments about moral accountability, and the ventral striatum for reward and pleasure. The neurotransmitters are glutamine and dopamine. The objective thinking brain locates in the dorsolateral prefrontal cortex for objective reasoning and analysis without bias. The neurotransmitter is glutamine. Objective thinking plays a limited role in decisions. According to Drew Westen [61], only between 0.5 and 3 percent of the most important political decisions utilize objective thinking. For rational civilization, the thinking brain formulas the rational rules to control both proactive aggression and reactive aggression.

\section{The Mega Empires and Worldviews}

The formation of centralized mega empires destroyed the tribal social structure based on territorial worldview. As a result, the new civilizations based on dis- 
crete or connective worldview emerged to replace territorial civilization based on territorial worldview.

\subsection{The Mega Empires}

Peter Turchin proposes a theory for formation of mega empires [62]. He proposes the mirror-empires model where antagonistic interactions between nomadic pastoralists and settled agriculturalists resulting in an autocatalytic process, which pressures both nomadic and farming polities to scale up polity size, and thus military power to become mega empires. Over $90 \%$ of mega empires arose within or next to the Old World's arid belt, running from the Sahara desert to the Gobi desert. Initially, such mega empires were decentralized mega empires consisting of dependent tribes inside empires and independent tribes outside empires.

The centralized mega empire social structure started from about 3000 years ago by the Iron Revolution. All major religions were established during this period. The Iron Age (the Iron Revolution) started between 1200 BCE and 600 BCE, depending on the region. Iron is tougher and lighter than bronze and was used to make much better sharp objects like spears, swords, and sharp tools than bronze. The source for iron was much more abundant than bronze. Through the Iron Revolution, the decentralized mega empires were converted to the centralized mega empires with iron technology. The earliest proto-mega centralized empire is the Hittite Empire based on the advantages entailed by its high advancement on ironworking at the time [63]. The Hittite Empire was not very large. The earliest mega centralized empires were the neo-Assyrian empire (934-609 BCE) and neo-Babylonian empire (612-539 BCE) which conquered many independent tribes. In China, Shang Dynasty (1570-1045 BCE) and Zhou dynasty (1046-256 BCE) were a decentralized mega empire. Qin dynasty (221-206 BCE) and Han dynasty (206-220 BCE) were the centralized mega empires. The sizes of centralized mega empires were much larger than the sizes of decentralized empires.

\subsection{Worldviews}

The mega empires that were produced from the antagonistic interactions between nomadic pastoralists and settled agriculturalists lost stable and rigid territorial boundary. As a result, in the mega empires, territorial worldview with rigid boundary was replaced by discrete worldview or connective worldview with flexible boundary. Nomadic pastoralists and settled agriculturalists have different worldviews. Settled agriculturalists developed connective worldview with extended ingroup. In sedentary settled agriculturalists, the main economic growth model was the economic gain in agricultural products from the investment in the complex infrastructures, such as market, transportation, and irrigation. The infrastructure involves both basic physical and organizational structures-facilities. Settled agriculturalists were motivated to form alliances in order to establish the infrastructures among city-states. As a result, settled agriculturalists developed 
connective worldview to view the world as connective city-states. Mobile nomadic pastoralists developed discrete worldview with extended outgroup. In mobile nomadic pastoralists without a fixed settlement for the complex infrastructures, the main economic growth model was the economic gain from the plundering of properties by conquest. The plundering of properties by conquest in nomadic pastoralists generated the discrete world, so nomadic pastoralists developed discrete worldview to view the world consisting of discrete clans.

According to R. E. Nisbett et al., most subsistence research has compared herders and farmers, arguing that the independence and mobility of herding make herding cultures individualistic and that the stability and high labor demands of farming make farming cultures collectivistic [64]. According to $\mathrm{T}$. Talhelm et al., within farming cultures, historically farming rice is more collectivistic than farming wheat, and such difference continues to affect people in the modern world [65]. Individualistic and collectivistic cultures essentially correspond to discrete and connective worldviews, respectively.

In the clash of agriculturalists and pastoralists, the ruling classes of mega empires could adopt either discrete worldview from pastoralists or connective worldview from agriculturalists. Discrete worldview with extended outgroup dominates the Western civilization originated the Middle East and Greece, while connective worldview with extended ingroup dominates the Eastern civilization originated from India and China. The East has not developed permanently aggressive discrete worldview as neither China nor India has reached beyond Asia. The discrete West pursues global military hegemony by defeating competitors in the perceived discrete world, and colonized almost the whole world during the 19th century. The connective East pursues international community to build the adaptable infrastructure for clothing, food, shelter, and transportation in the perceived connective world. Therefore, the discrete Western civilization and the connective Eastern civilization are basically discrete chimpanzee-like civilization with high propensity for proactive and reactive aggressions and connective bonobo-like civilization with low propensity for proactive and reactive aggressions, respectively as in Table 3.

Instinctive worldview affects social interaction and perceptions. In relational sociology [66], substantivalism considers individuals as self-subsistent entities capable of social interaction, while relationalism considers the social human practices and the individual's transactional contexts and reciprocal relations.

Table 3. The mega empire civilizations.

\begin{tabular}{ccccc}
\hline Civilization & Originated from & $\begin{array}{c}\text { Original dominant } \\
\text { social structure }\end{array}$ & Worldview & $\begin{array}{c}\text { Proactive and } \\
\text { reactive aggressions }\end{array}$ \\
\hline Western civilization & $\begin{array}{c}\text { Middle East } \\
\text { and Greece }\end{array}$ & nomadic pastoralists & $\begin{array}{c}\text { Discrete worldview } \\
\text { with extended outgroup }\end{array}$ & Chimpanzee-like \\
Eastern civilization & India and China & settled agriculturalists & $\begin{array}{c}\text { Connective worldview } \\
\text { with extended ingroup }\end{array}$ & Bonobo-like \\
\hline
\end{tabular}


Substantivalism corresponds to discrete worldview where individuals stand alone to compete against one another, while relationalism corresponds to connective worldview where connective individuals are related to one another. In terms of perception, substantivalism and discrete worldview percept an objects as identity standing alone, relationalism and connective worldview percept an object to have relation with another object. As a result, the Westerners with discrete worldview pay attention to the focal object separated from its surrounding based on discrete perception, while the Easterners with connective worldview attend more broadly to the overall surroundings and to the relations between the object and the field [13] [14]. One typical way to identify the East vs the West is to pair panda, monkey, and banana. Typically, the Westerners pair panda and monkey for the same category (animals), while the Easterners pair monkey and banana for the relationship (monkey eats banana). According to sociologists G. Jiang, T. Lo, and C. Garris, such relational (guanxi) phenomenon is currently in many countries, including China, Russia, Japan, Korea, Haiti, and Arab countries which adopt connective worldview [67].

\subsection{Religions for Mega Empires}

Before mega empires, many tribes or city states resulted in decentralized union of hierarchical states with rigid boundary. The union could be the alliance of states or a mid-size overlord empire with a number of client states. At that time, no single state was strong enough from available technologies to centralize the powers in the union. The lack of centralized power was manifested in pluralistic state theism with polytheism. In polytheism, the chief deity was typically remote, and people worshiped their local deities. One typical example of polytheism is the polytheism in Canaan. Canaan, an ancient region between the River Jordan and the Mediterranean, located in the Levant region of present-day Lebanon, Syria, Jordan, and Israel. The chief deity was El. Israel was derived from Isra + El instead of Isra + Yahweh. During the Bronze Age and the early Iron Age, each nation had its own local deity under El [68]. Israel and Judah shared Yahweh as their national god. The various national gods were more or less equal. Because of the intermarriages and alliance among these nations, each nation had altars for the national gods of neighboring nations. According to archeological evidence [69], during this time, idols represented other religions were found commonly in Jewish homes.

With territorial worldview, each state could maintain its own deity within its boundary, so polytheism was viable before the mega empires. In the West, the mega empires defeated all small tribes with their territorial tribal gods in the form of polytheism. As a result, under discrete worldview where all religions were discrete and competitive, polytheism was no longer viable. In the West, under a mega empire with flexible boundary, only monotheism where the whole world without any boundary had only one god was viable. In the mega empires of the West, monotheism became the foundation of the open civilization with flexible boundary. 
The earliest mega centralized empire with monotheism is the Persian Empire (550-330 BCE) with monotheistic Zoroastrianism. Zoroastrianism was found by the prophet Zoroaster traditionally dated to the 6th century BCE in the Iron Age after and during the time of the mega centralized neo-Assyrian and neo-Babylonian empires. Polytheism did not work well in mega centralized empire, resulting in the rise of monotheism. Zoroastrians believe in one God, called Ahura Mazda (meaning "Wise Lord"). He is compassionate, just, and is the creator of the universe. Zoroaster placed less emphasis on ritual worship, instead focusing on the central ethics of "Good Words, Good Thoughts and Good Deeds".

In Israel and Judah, the failure of polytheism as the alliance of deities for the alliance of states led to the development of monotheism. In $722 \mathrm{BCE}$, Israel was defeated by the mega Assyria Empire which was strong enough to defeat various states with enormously destructive army and iron weapons. Israelites witnessed the failure of polytheism with the alliance of deities for the alliance of states. No alliance could defeat the mega Assyria Empire who looked down at all local deities. To some Israelites, the only salvation was to convert the local deity of Yahweh into the imaginary mega universal deity of Yahweh who had the power over all earthly empires. The mega universal deity of Yahweh was the only answer to oppose the mega emperor of the mega Assyrian Empire [70]. The mega universal deity was monotheism. Some of the refugees who fled from Israel to Judah brought with them the Yahweh only monotheism to Judah, and convinced some very influential people to believe in monotheism replacing polytheism. Several kings in Judah became the strong supporters of monotheism. The Jewish prophets, such as Isaiah, Jeremiah, and Ezekiel, became the spokesmen for monotheism. To the believers of monotheism, the practice of polytheism by Israelites was the reason for the defeat and suffering of Israelites as the punishment by monotheistic Yahweh. However, Yahweh, the universal deity, would not abandon Israel-Judah, and one day Israel-Judah would rise again under monotheistic Yahweh. Judaism is very restrictive with various rules and traditions. Christianity with much less rules and traditions is basically a broaden Judaism appealing to all people, and maintains monotheism to appeal to mega centralized empires. Eventually, the mega centralized Roman Empire adopted Christianity as the state religion. Islam is also monotheism suitable to mega centralized empires.

In the East from India and China, mega empires with flexible boundary adopted connective worldview where all religions and gods were connected and cooperative. In the mega empires of the East with connective worldview, all religions and deities were connected into Henotheism (theism of one god) to worship a single god without denying the existence or possible existence of other deities. Hindus worship one formless Supreme Being called Brahman though by different names. Hindus believe in many gods who perform various functions, and gods are connected through reincarnations, family relations, and functions. Similarly, Chinese under mega empires worshiped one formless Supreme Being named Tien (Heaven). Chinese at the same time worship many other gods, spirits, and ancestors. Chinese worship different gods for different functions. To 
worship one god under monotheism is incomprehensible to traditional Indians and Chinese.

\section{The Axial Age and Social Orders}

The human social order has evolved with the evolution of human social structures and worldviews. The new social orders emerged during the Axial Age from about the 8th to the 3rd century BCE [15].

\subsection{The Pre-Civilization without Rational Rule}

In the early pre-civilized society, the social order depended on the instinctive social brain and the instinctive mental immune system. Such social instinct for social order is called conscience. No evidence for extensive religious practice has been found in the early pre-civilized society [71], so the original conscience was not religious. In the late pre-civilized society, the social order depended on the instinctive social brain, the instinctive mental immune system, and theory of imaginary mind to improve intergroup interaction and mental immune system in order to overcome the harsh environment of the Upper Paleolithic Period and form cooperative hunter-gatherer bands [51] [72]. Religion became an important part of social order in large cooperative pre-civilized hunter-gatherer bands which did not need any rational rule. In the pre-civilization, the social order depended on the social brain for instinctive intragroup relations and worldviews to form the original human social group, the mental immune system for instinctive mental therapy, and theory of imaginary mind for imaginary religious and political entities with their own minds to form cohesive large social groups.

\subsection{The Territorial Tribal Rational Civilization Based on Rule of Boundary}

After the Agricultural Revolution, a large orderly civilized tribe with rigid boundary has territorial worldview and rule of boundary enforced by boundary system to separate ingroup and outgroup where individuals in ingroup are good, and individuals in outgroup are bad. As a result, in rule of boundary, rule for ingroup is different from rule for outgroup. Rule for ingroup is rule of moralized relational based on the explicit, standardized, and rational morality for instinctive intragroup relation including commitment for family, reciprocity for alliance, interdependence for division of labor, and generativity for multigeneration. The totality of morality is love which is to connect to all individuals (in the past, present, and future) in the ingroup. Moralized relational rule deals with connective and related individuals in ingroup, and is enforced by honor and shame for the fulfillment and unfulfillment, respectively, of relational rule. Shame in moralized relational rule relates to reactive aggression toward the ingroup, and the aggressor (judge) has connection with the individual (sinner) in shame (humiliation). Moralized relational rule is enforced by reactive aggression. The enforcement agent is the manner system for relation in terms of 
rites, etiquette, and customs among individuals in ingroup to reinforce relation, and each individual in the manner system is relational with pre-existing relation.

Rule for outgroup is rule of law as legalized contract rule including contracts among traders from different tribes and treaties among the chiefs of different tribes. Such legalized contract rule is basically arbitrary contract. Legalized contract rule deals with discrete and independent individuals, and is enforced by reward and punishment for observation and violation, respectively, of legalized contract rule. Punishment in legalized contract rule relates to proactive aggression toward outgroup, and the aggressor (judge) has no connection with the individual (violator) in punishment. Legalized contract rule is enforced by proactive aggression. The enforcement agent is the legal system for legalized contract rule, and each individual in the legal system is independent without pre-existing relation.

Later, when a large civilized tribe contained a large numbers of permanent foreign traders and new immigrants, ingroup became ambiguous and heterogeneous. To such large ambiguous and heterogeneous ingroup, moralized relational rule was not enough, and had to be assisted by legalized relational rule which legalized moralized relational rule. Legalized relational rule is natural law with the moral rule of natural human relations [73]. In terms of the enforcement, legalized relational rule is not different from legalized contract rule enforced by reward and punishment. An early written legalized relational rule for a government was the Code of Hammurabi, dating from 1750 BCE. Hammurabi, the King of Babylon, needed to unite his disparate realm, and decided to establish common rules of conduct, commerce, and devotion to the king under a system overseen by judges. Therefore, a large civilized heterogeneous tribe usually had both moralized relational rule and legalized relational rule for ingroup, and separate legalized contract rule for outgroup. Legalized contract rule becomes artificial law based on consent without the moral rule of natural human relations.

The pre-civilized society and the small civilized society were egalitarian. The large civilized territorial tribal society was highly hierarchical, so it had both territorial boundary toward outgroup and hierarchical boundary toward ingroup involving the boundary between the ruling class and the laboring class. As a result, the large hierarchical tribe spent extraordinary amount of resource to produce the extremely elaborate symbols, such as palaces, temples, graves, dresses, and jewelries, only for the ruling class to establish the hierarchical boundary separating ruling class and laboring class. The ruling class claimed that such extremely elaborate symbols which required extremely elaborate thinking gave them the power to rule. Egyptian pyramids were such elaborate symbols. Only tribal civilization spent so much resource proportional to the total tribal resource in such elaborate symbols which appeared to work well for the ruling class to rule a large population. 


\subsection{The Axial Age}

The rise of the mega empires destroyed tribal territorial and hierarchical boundaries, and produced the great rational thinkers in the Axial Age to establish the new rational social orders for the mega empires. The great rational thinkers include Confucius and Laozi in China, Buddha and the writers of the Upanishads in India, Zarathustra in Iran, Isaiah, Jeremiah, and Ezekiel in the Middle East, and Socrates, Plato, and Aristotle in Greece. They replaced territorial worldview based on rule of boundary with rigid territorial and hierarchical boundaries by discrete or connective worldview with flexible territorial and hierarchical boundaries. Moralized relational rule becomes rule of relation for all people with flexible boundary, while the combination of legalized relational rule and artificial law becomes rule of law for all people with flexible boundary. The great rational thinkers produced discrete and connective rational civilizations. To the great rational thinkers, territorial rational civilization based on rule of boundary was obsolete in the age of mega empires.

\subsection{The Discrete Western Rational Civilization Based on Rule of Law}

In the West, the great rational thinkers based on discrete worldview changed legalized relational rule by law with rigid territorial and hierarchical boundaries to rule of law with flexible territorial and hierarchical boundaries. As a result, rule of law deals with the extended outgroup among discrete and independent individuals with flexible boundary. No one is beyond and above rule of law. To discrete worldview, the human nature for all individuals is basically bad, so rule of law is required to control all individuals who are basically bad which is called "original sin" derived from the Bible. All discrete individuals are under one standard rule of law enforced by reward and punishment for observation and violation, respectively, of rule of law. Punishment in rule of law relates to proactive aggression toward the extended outgroup, and the aggressor (judge) has no connection with the individual (violator) in punishment. Rule of law is enforced by proactive aggression.

Jews observe Torah which includes all Jewish law, and was given to Moses in written form. To the Jewish prophets, no Jews anywhere was beyond and above the Jewish law. In Athens, Greece, all citizens had the right to bring both private and public matters before the courts maintained by magistrates and jurors from peers. The Athenian legal system appears to have worked efficiently. The commercial law in Athens introduced the principle of binding and enforceable contracts among equal citizens, and helped to make Athens the region's center for trade.

Plato implicitly developed rule of law based on universal natural law. According to Plato, we live in an orderly universe based on the Form of the Good in the brightest region of Being. The Form of the Good is basically the natural human relation which is evolved to form the original orderly human society. In the Republic by Plato, the ideal community is "a city which would be established in 
accordance with nature". Aristotle recognized that the rule of law required the separation of powers, including legislative branch to make the rule of law, the executive branch to enforce the rule of law, and the judicial branch where individual judges base their decisions solely on facts and law of individual cases independently of either the executive or legislative powers. This separation of powers for the rule of law served as a direct model of government for the writers of the American constitution.

\subsection{The Connective Eastern Rational Civilization Based on Rule of Relation}

In the East, the great rational thinkers based on connective worldview changed moralized relational rule with rigid territorial and hierarchical boundaries to rule of relation with flexible territorial and hierarchical boundaries. As a result, rule of relation deals with the extended ingroup among connective and related individuals with flexible boundary. No one is beyond and above rule of relation. To connective worldview, the human nature for all individuals is basically good, so rule of relation instead of rule of law is needed to cultivate the basic good instinctive nature in all individuals. All connective individuals are under one standard rule of relation enforced by honor and shame for the fulfillment and unfulfillment, respectively, of rule of relation. Shame in rule of relation relates to reactive aggression toward the extended ingroup, and the aggressor (judge) has connection with the individual (sinner) in shame. Rule of relation is enforced by reactive aggression. Rule of relation is rule of extended intragroup relation with flexible boundary.

In Confucianism, individuals are not discrete and independent, and all individuals are in relations with other people. Philosopher $\mathrm{Hu}$ Shih states, "in the Confucian human-centered philosophy man cannot exist alone; all action must be in the form of interaction between man and man" [11]. The five relationships in the extended ingroup are the relationships of ruler to subject, parent to child, husband to wife, elder sibling to younger sibling, and friend to friend. Each person has obligation and responsibility in all five relationships. The relationships are based on benevolence (ren) for the connection in the extended ingroup, righteousness $(y i)$ for right behaviors and roles in the extended ingroup, and rite or manner (li) for the manner system among different roles in the extended ingroup. ren and yi are more at the level of consciousness, and $l i$ in its expression, including etiquette and customs. To Confucius, the manner system worked better than the legal system. A child who grows up in such manner system automatically has the perspective of relation. Worldview is expressed as harmony. "In practicing the rules of propriety, it is harmony that is prized" (Analects 1: 12). Harmony is prized among the differences. Confucius said: "Noble persons seek harmony but not sameness. Petty persons seek sameness but not harmony" (Analects 13: 23).

In India, rule of relation was the Varna (caste) system based on division of labor in terms of division by professions (Brahmin Varna for priests and thinkers, 
Kshatriya Varna for rulers and warriors, Vaishya Varna for merchants and skill workers, and Shudra Varna for labors). Human interdependent relation for division of labor is instinctive as the prehistorical hunter-gatherer society was divided into hunter profession and gatherer profession. In the Hindu Vedas, the Varna is actually not equivalent to caste which is a Western word. "Varna" means one that is adopted by choice. "Caste" means one that is adopted by birth. In Vedic culture, everyone is considered to be born as Shudra. Through education, one becomes a Brahmin, Kshatriya or Vaishya. This completion of education is considered to be a second birth to obtain the status of "Dwija" (twice-born) for a Brahmin, Kshatriya or Vaishya. However, due to frequent foreign invasions, the Varna system became more rigid to protect the Varna system from the foreign invaders [74].

Buddhism adopts connective worldview mentally and socially as in the Buddhist principle of dependent origination (pratityasamutpada) where all phenomena arise in dependence upon other phenomena. The principle of dependent origination results in the doctrine of sunyata (voidness) without discrete self-existence independent of other existences. On the other hand, discrete worldview has discrete self. Buddhism teaches that the mind based on discrete worldview causes suffering by attaching to discrete self which does not exist in connective worldview. The way to reduce suffering is to replace discrete worldview with connective worldview, resulting moving from discrete outgroup to connective ingroup.

As shown by psychologists Igor Grossmann and Ethan Kross [75], Russians (members of an interdependent culture) with connective worldview tend to be more communal, more focused on interpersonal harmony, and this allows them to see their own personal needs in larger context, from an outsider perspective. Americans (members of an independent culture) with discrete worldview, by contrast, tend to focus on the personal. With less of a community perspective, they immerse themselves in the emotional details of negative events, and this self-focus leads to distress and depression, resulting in more distress and a less adaptive than Russians. These findings demonstrate how worldview shapes the way people reflect over negative experiences.

As shown by Sara W. Lazar et al. [76], the result of magnetic resonance imaging showed the increase in cortical thickness in 20 participants with extensive Insight meditation (such as calm mindfulness of breathing) experience. The cortex involves in the thinking brain. The observation indicates that the Buddhist meditation involves rational thinking. In the Western psychotherapy by psychoanalysis, the rational thinking involves the rational analysis of discrete self. By finding out the true discrete self, one can control the emotion from the true discrete self. On the other hand, in the Buddhist insight meditation, the rational thinking involves the calm rational monitoring (mindfulness) of whole self (such as breathing) without analyzing discrete self. By strengthening the cortical monitoring of whole self, one can control the emotion in the whole self. The Buddhist meditation [77] has been investigated to show the decreases in emo- 
tional interference by unpleasant stimuli and in the time to return to emotional baseline after stress.

\subsection{Interdependent Coexistence}

The Western mega empires adopted discrete worldview to produce the governmental rule of law for all citizens. Moralized relational rule from connective worldview, on the other hand, were produced by local religions and customs. For example, Jews were allowed to practice the Jewish legalized relational rule without all legal enforcement. Basically, local people could practice moralized relational rules with their own moral standards enforced by honor and shame, and the mega empires had the governmental rule of law enforced by reward and punishment. In this way, the Western mega Empires had the governmental rule of law as the principal rule and local relational rule as the auxiliary rule. The principal rule and the auxiliary rule were interdependent.

In the West, the principal rule in Christianity is rule of law as the base of the final judgment at the end time for reward and punishment. At the same time, Christianity has auxiliary rule of loving relations between God and people and among believers with Jesus' death and blood as the redemption to redeem his believers from rule of law to rule of loving relations.

In China, the Qin dynasty was the first mega centralized empire (221-206 BCE) with legalism with rule of law which relied on clear laws and strict punishments for all people. The emperor (Qin Shi Huang) attempted to destroy all other schools of philosophy. Legalism that built the strong and well-organized Qin Empire had a narrow appeal. As a result, the Qin dynasty was ended quickly after his death. The Han dynasty (206 BCE-220 AD) after the Qin Dynasty adopted Confucianism with rule of relation as the official ideology, and retained rule of law under Legalism. Different dynasties had different sets of law. As a result, China had the Confucian rule of relation as the principal rule and the Legalist rule of law as the auxiliary rule which was used only after the failure of rule of relation. The principal rule and the auxiliary rule were interdependent.

\subsection{The Rise and Fall of Mega Empires}

In the book "War and Peace and War: The Rise and Fall of Empires" [77], Peter Turchin showed that mega empires arise where civilizations clash, and successful empires tend to expand by cultural assimilation. For example, when pastoralist and agriculturalist civilizations clash, people from each civilization have to band together to fight off a common enemy, resulting in the social cohesiveness to form mega empires. Successful empires depend not only on the social cohesiveness but also the rational rules to assimilate different tribes in mega empires. In this way, different tribes in an empire accept the rational rule of the empire without the original rigid boundary among tribes.

However, Peter Turchin shows that the evolution from tribes to a mega empire is reversible. As a mega empire grows, population outgrows the carrying capacity, producing general decrease in common wellbeing. Wars, economic 
conflicts, technological changes, and natural disasters can also result in the decrease in common wellbeing. The decrease in common wellbeing brings about the severe internal competition. Inequality, social stratification, the competition among elites, and the depletion of state resource increase over time. The result is the breakdown of the social cohesiveness and the rational rules. Without the social cohesiveness and the rational rules, a mega empire returns back to conflicting tribes with rigid boundary. The reduction of the sizes of elite class and laboring class during the tribal conflict allows a new mega empire to emerge with sufficient resource. When people bring back the social cohesiveness and the rational rules, mega empires and peace are restored.

The mega empires produced all major religions based on discrete or connective rational civilization. The major religions maintain the rational way of life based on discrete or connection rational civilization. The fall of the Roman Empire produced territorial rational civilization within discrete rational civilization maintained by major discrete religions.

\section{The Industrial Revolution and Democracies}

The Industrial Revolution has changed human society drastically to produce new national and international political and economic systems. Democracy is one of new systems.

\subsection{The Industrial Revolution}

During the 18th century, the Age of Enlightenment centered on reason as the primary source of knowledge dominated the world of ideas in Europe. The ideas, such as nationalism, liberalism, and socialism of the Enlightenment undermined the authority of the monarchy and the Church, and paved the way for the political revolutions of the 18th and 19th centuries. At the same time, the Industrial Revolution in Europe changed the power structure of society and improved educational and living standard of people, especially the middle class people. The European population increased from 140 million in 1750 to 266 million in 1850 due the improved living standard. As a result, through the improvement in education and living standard, the Industrial Revolution expanded elite democracy for few people to democracies for most or all people in a nation. Derived from the ancient Greek "demokratia", democracy literally means that power (kratos) belongs to the common people (demos). In democracy, power belongs to the common people instead of dictators, inherited kings-queens, and inherited aristocrats. The democracies include territorial nationalist democracy, discrete liberty-equality democracy, and connective common wellbeing democracy.

The Industrial Revolution contains four stages. The first industrial revolution began in Britain in the late 18th century. It was centered on textiles, steam power, and iron. The second industrial revolution was between 1870 and 1914 after the civil war in America. It was centered on steel, railroads, petroleum, chemicals, and electricity. The third industrial revolution as the information revolution 
began in the 1980s with the proliferation of digital computers, digital record, personal computers, the internet, and information and communications technology. The fourth industrial revolution builds on the third industrial revolution, and combines robotics, artificial intelligence, nanotechnology, quantum computing, biotechnology, the Internet of Things (IoT), decentralized consensus, 3D printing, and autonomous vehicles [78]. The fourth industrial revolution allows highly individualized global production-distribution-information. The increasing advancement of the Industrial Revolution favors globalization.

\subsection{Territorial Nationalist Democracy (Tribalism Democracy)}

Territorial nationalist democracy is a competitive democracy based on territorial rational civilization. Basically, territorial nationalist democracy is tribalism democracy for the majority tribe in a nation. Nationalism was derived from people's awareness of being part of a nation with common institutions, traditions, language, and customs. Nationalists owe their chief political loyalty to the nation rather than to a dynasty, city-state, or other political unit. Nationalism became a popular force for change by the French Revolution. Nationalism destroyed the old order of monarchies in Europe. Nationalist economy is the state-controlled economy to promote nationalism. Currently, the rapidly changes in globalization and automation produce the problems of gross income inequality, serious job insecurity, and large scale immigration. The countries that cannot deal with such problems shift toward nationalist politics with nationalist economy which blames non-traditional groups and foreign countries for such problems.

The main issue in the international relation for territorial nationalist democracy is national boundary. At the end of World War II, there were seven border walls or fences in the world. By the time the Berlin Wall fell in 1989, there were 15. Today, there are at least 77 walls or fences around the world-many erected after the September 11,2001, terrorist attacks in New York City and at the Pentagon. The international relation for nationalist democracy is the boundary international order which promotes the establishment of national boundary in the world.

\subsection{Discrete Liberty-Equality Democracy (Individualism-Egalitarianism Democracy)}

In the discrete rational Western civilization, individuals are discrete and independent. The two basic goals for discrete and independent individuals are liberty and equality. In terms of civilization, liberty for individual liberty comes from ancient Greek individualism, while equality for equality in individual power comes from early Israelite egalitarianism [79]. Basically, discrete liberty-equality democracy is individualism-egalitarianism democracy for all people in a nation. The method to reach such goals is competition among discrete and independent individuals. Politically, the people with similar goal form political party to pursuit their goal. There are multiple political parties to pursuit multiple goals. The 
multi-party system is the main political driving force, because most people are not active, well-informed, and interested in politics. The rational rule is rule of law for all people. The result is competitive multi-party liberty-equality democracy based on rule of law.

Competitive multi-party democracy for liberty is liberal democracy. Liberalism based on Enlightenment principles held that people should have liberty as much as possible from government restraint. In the Age of Enlightenment, liberalism sought to liberate individuals from the authoritarian restrains of hereditary privilege, state religion, absolute monarchy, and the divine right of kings. Philosopher John Locke is often credited with founding liberalism based on the social contract which provides each person a natural right to life, liberty, and property. The Glorious Revolution of 1688, the American Revolution of 1776, and the French Revolution of 1789 used liberalism to justify the revolutions against authoritarian tyrannies. Liberal economy is the individual-controlled economy to promote liberty. Liberal economy involves free markets and private ownership of capital assets. Liberal economy opposes non-liberal economies, such as socialist economy, planned economy, and protectionism. The economic liberty is expressed in the laissez-faire doctrine in The Wealth of Nations (1776) by the Scottish economist and philosopher Adam Smith. According to Smith, competition in free trade benefits all parties, because competition leads to the production of more and better goods at lower prices. Any other arrangement, whether state control or monopoly, must lead to regimentation, exploitation, and economic stagnation.

Competitive multi-party democracy for equality is socialist democracy. Henri de Saint-Simon (1760-1825) in France created the term "socialism" as a contrast to liberal individualism which failed to address poverty, social oppression, and gross inequalities in wealth social concerns during the Industrial Revolution in Europe. To achieve equality, he presented socialism as an alternative to liberal individualism based on the shared state ownership of resources. Different models of socialism have different degrees of state ownership and administration of the means of production and distribution of goods to produce different degrees of equality. The equality in socialist democracy includes at least the basic equality in healthcare, education, and basic income, and is not absolute equality in all aspects. Therefore, socialist democracy is still competitive other than basic equality.

The international relation for liberal democracy is to establish liberal international order as multilateral rule-based liberty in politics and economy in terms of liberal democracy and internal and international free market. Liberal international order promotes and assists liberal democratic movements in other countries. Liberal international economic order established the World Trade Organization to create and implement free trade agreements, the World Bank to provide aid to developing countries, and the International Monetary Fund to foster global monetary cooperation, secure financial stability, facilitate international trade, promote high employment and sustainable economic growth, and reduce 
poverty around the world. Liberal international economic order has contributed the global economic growth. The international relation for socialist democracy is to establish socialist international order based on equality. During the Cold War, socialist international order for classless state led by the USSR promoted classless state, equality, and solidarity. One of the major international organizations for socialist international order is the Socialist International whose origins go back to the early international organizations of the labor movement, has existed in its present form since 1951, when it was re-established at the Frankfurt Congress. It currently brings together 147 socialist democratic parties and organizations from all continents. The Socialist International continues assist socialist democratic parties globally. The Socialist International also involves environmental international order based on equality between human impact and environment. Environmental international order produced the Paris Agreement to protect global environment. Environmental international order is strong in Europe.

\subsection{Connective Common Wellbeing Democracy (Collectivism-Meritocracy Democracy)}

In the connective rational Eastern civilization, individuals are connective and related. The basic goal for connective and related individuals is common wellbeing. Basically, connective common wellbeing is collectivism democracy under meritocracy for common wellbeing of all people in a nation. Meritocracy based on merit is not egalitarian. Common of common wellbeing is derived from collectivism, and wellbeing is provided by meritocracy. Meritocracy is equivalent to professional qualification. The method to reach such goal is cooperation among connective and related individuals. The democracy is connective common wellbeing democracy which avoids the impractical and messy competition among well-to-do discrete elites who seek selfish self-expressions in discrete liberty-equality democracy. Politically, the people with such goal of common wellbeing form political party to pursuit their goal. There is one-party to pursuit the goal of common wellbeing. The one-party system is the main political driving force, because most people are not active, well-informed, and interested in politics. A government in common wellbeing democracy focuses in the infrastructure for the common wellbeing of all people as a whole, in developing all-round economy to avoid vulnerability to hurt the whole economy, and in maintaining long-term view for the future generations. By improving common wellbeing, individual wellbeing will be improved soon or later in terms of generations.

The world currently is dominated by discrete liberty-equality democracy. Connective common wellbeing democracy is in minority, and practiced by few countries, including Singapore, China, Vietnam, Russia, and some Muslim countries which have connective worldview instead of discrete worldview [67]. In 1978, Deng Xiaoping [80] started common wellbeing democracy by establishing the goal of moderately well-off society through reform and opening based on cooperative rule of relation. He moved away from the Western com- 
petitive outright individual liberty and equality which do not exist in the traditional Chinese connective worldview. He moved the political system toward cooperative and practical common wellbeing democracy with Chinese character based on connective worldview. Connective common wellbeing democracy has worked well in China. Such connective common wellbeing also involves meritocracy as professional qualification. In terms of professional qualification, Deng Xiaoping famously said that it doesn't matter if a cat is black or white so long as it catches mice. Common wellbeing democracy is the most practical democracy which uses the best mixtures of methods to improve the common wellbeing of people. As a result, it uses the mixture private owned enterprise (POE) and state owned enterprise (SOE). Much more people work for POE than SOE in China. It uses the mixture of election and professional qualification (meritocracy) as described by Daniel A. Bell [81]. Common wellbeing democracy also uses experiments frequently to test new policies before the national implementations of new policies.

According to the World Bank, more than 850 million Chinese people have been lifted out of extreme poverty; China's poverty rate fell from 88 percent in 1981 to 0.7 percent in 2015 [82]. China has eradicated poverty at the rate of poverty reduction and at the number of poor people reduction unmatched anywhere and anytime in the world. China continues actively to industrialize and to eradicate poverty especially in the poor and remote rural areas. Another country with the similar political system and the similar rate of poverty reduction as China is Vietnam. The General Statistical Office in the World Bank estimates that the poverty rate fell consistently from 58 percent in 1993 to 14.5 percent in 2008. Some 28 million people are estimated to have been lifted out of poverty over approximately one and a half decades, an achievement widely applauded [83]. Connective common wellbeing democracy based on rule of relation is a good political system to eradicate poverty and increase wealth. No country based on liberty-equality democracy has achieved such rate of poverty reduction.

The basic assumption of the common wellbeing international order for common wellbeing democracy is that no nation stands alone, and all nations are related to one another in the community of common destiny that produces wellbeing as the state of being comfortable, healthy, secure, and happy. One way to implement common wellbeing international order is through infrastructural international order to connect various countries and regions such as the Road Belt Initiative (BRI) proposed by Xi Jinping in September and October 2013 during visits to Kazakhstan and Indonesia [84]. It involves infrastructure development and investments in 152 countries and international organizations in Asia, Europe, Africa, the Middle East, and the Americas. The origin of the BRI is The Silk Road started by China's Han Dynasty (206 BC-220 AD), which forged trade networks throughout what are today the Central Asian countries, Indi, Pakistan, and Europe. Use of the route peaked during the first millennium, under the leadership of first the Roman and then Byzantine Empires, and the Tang Dynasty (618-907 AD) in China. The BRI involves the overland Silk Road Economic Belt 
and the Maritime Silk Road. The BRI also plans to build fifty special economic zones to launch economic developments quickly. The BRI helps the economic developments in developing countries. With adequate wellbeing in all nations, the large scale migration of people from poor nations to rich nations can be minimized. Morgan Stanley has predicted China's overall expenses over the life of the BRI could reach $\$ 1.2-1.3$ trillion by 2027. In comparison, America has spent \$5.9 trillion on wars in the Middle East and Asia since 2001. The three democracies and international relations are listed in Table 4.

\subsection{Interdependent Coexistence}

Any robust democracies have interdependent coexistence of competitive democracy and cooperative democracy. In current politics, according to the Democracy Index by the Economist Intelligence Unit, the best liberal democracy countries are the Nordic countries based on both rule of law to deal with partisan and market competitions and rule of relation for the common wellbeing of all people in terms of the universal health care-welfare system and education system. In Singapore, the politics is essentially one-party connective politics with effective programs for the common wellbeing of all citizens, but it has rule of law to deal with market competition as the most competitive economy in the world according to the Global Competitiveness Report 2019 from the World Economic Forum. As a result, a robust liberty-equality democracy has common wellbeing democracy as the auxiliary democracy, while a robust common wellbeing democracy has liberty-equality as the auxiliary democracy.

\section{Globalization and Tribalization}

The Industrial Revolution brings about intensive international interactions which cause international interdependence in raw materials, technologies, productions, markets, labors, and capitals. No country can survive well by itself. The two possible world communities are the globalized integrated community and the internationalized interdependent community. The internationalized interdependent community allows interdependent coexistence of the three rational civilizations.

\subsection{Globalization}

Ever since the first Industrial Revolution, industrialization has impacted in both

Table 4. The three democracies and international relations.

\begin{tabular}{ccccc}
\hline Democracy & Worldview & Rule & Political party & International relation \\
\hline Nationalist & Territorial & Rule of boundary & Multiple parties & $\begin{array}{c}\text { Boundary } \\
\text { international order } \\
\text { Liberty-equality }\end{array}$ \\
Discrete & Rule of law & Multiple parties & $\begin{array}{c}\text { Liberal-socialist } \\
\text { international order }\end{array}$ \\
Common wellbeing & Connective & Rule of relation & One party & $\begin{array}{c}\text { Common wellbeing } \\
\text { international order }\end{array}$ \\
\hline
\end{tabular}


economic and cultural globalizations. In particular, advances in transport and telecommunications have had a huge impact in globalization. In economy, with increasing trade and communication, more and more international corporations are extending their reach across land and sea. Mega international corporations become the main driving force for globalization. To a mega international corporation, globalization is often offered as the strategic effort to treat the world as a single market in which to do business, a single research and development laboratory, a single production center, a single logistics network, and a single headquarters site [6]. A mega international corporation has no national boundary among nations. Basically, mega international corporations to economic globalization in the world are similar to mega empires to imperialization in large regions in terms of the elimination of boundary.

The global economy grows more with economic globalization as shown by Jagdish Bhagwati [8]. The result of globalization is "the globalized integrated community" based on rule of integration which is established by the World Bank (WB), International Monetary Fund (IMF), and World Trade Organization (WTO) as described by Herman Daly [7]. Such rule of integration is based on liberal democracy and free market established by advanced industrial countries, such as America and the West European countries. Under the globalized integrated community, national boundary is basically open, and the purpose of globalization is to maximize the efficiency of international corporations and the global economic growth as described by Economist Jagdish Bhagwati [8].

\subsection{Tribalization}

Globalized corporations benefit from globalization, because in a globalized economy with free capital mobility, nations no longer specialize in their own "comparative advantage", but instead global capitalists and corporations follow "absolute advantage"-allocating their resources to maximize global productivity and global profit as shown by Herman Daly [17]. However, a nation loses its ability to enforce its own laws and standards which become meaningless in a globally integrated economy without national boundary. The Industrial Revolution produces both globalization and automation. In economic globalization and automation, people who are competitive in the globalization and automation get rich and secure, and people who are not competitive in globalization and automation become poor and insecure. Without proper help from governments, the wealth gap between the rich and the poor increases with increasing globalization-automation. In the USA, from 2009-2012, over 90\% of new income accrued to just the top $1 \%$ of income earners. As the economy recovered further, new income distribution was less lopsided, but still uneven. The top $1 \%$ captured over half of all income growth in the US over the period 2009-2015 [85]. In 2013, the bottom 50\% of families held 1\%, and inequality worsened from 1989 to 2013 [86]. According to The New York Times, the richest 1 percent in the United States now owns more wealth than the bottom 90 percent [87]. Economic globalization-automation is unfair. 
To some countries, globalization includes economic, political, and military globalizations. Military globalization involves the military presence in terms of overseas military bases and navy ships all over the world. The military globalization has started pre-empt wars and proxy wars in the Middle East far away from home, resulting in endless and futile wars. With so much advancement in very expensive weapons, expensive military globalization can no longer be maintained by one country. The top three military countries have not engaged in direct war since the Korea War over sixty years ago, and any direct war among them appears to be unlikely. As a result, military globalization is futile and useless.

The dominant discrete liberty-equality democracy wants to globalize political system by discrete worldview. Different civilizations have different worldviews. To globalize one political system in different civilizations appears to be futile and disrespectful to diverse civilizations. The globalization of liberty-equality democracy in Middle East has resulted in disasters causing instability and great human suffering. The world now has less liberty-equality democracy than before. Military-political globalization is futile.

As shown by Koert Debeuf in "Tribalization: Why war is coming" [16], the end of globalization is tribalization. The large gap between the rich and the poor in unfair economic globalization-automation brings about tribalization in terms of protectionism with rigid political, economic, and social boundary to minimize globalization. The military-political globalization in the Middle East has produced the tribalization in the Middle East through the invasion, proxy wars, and the Arab Spring. Different religious and ethnic tribes now fight against one another in many areas in the Middle East, resulting in chaos and great human suffering. Political globalization has also started the proxy tribalization wars to support the tribalization in their opponents in order to weaken their opponents. In discrete liberty-equality democracy, the tribalization involves the tribalization of political parties. Ukraine has been tribalized completely by military-political globalization, resulting in suffering and poverty. No country is safe from the proxy tribalization war from her opponents who attempt futilely to globalize military and politics, even though the tribalization brings about chaos and poverty. Unfair economic globalization and futile military-political globalization produce tribalization which brings about chaos and poverty instead of peace and wellbeing.

\section{Internationalization and the Interdependent Coexistence of the Rational Civilizations}

Since unfair economic globalization and futile military-political globalization produce tribalization which brings about chaos and poverty instead of peace and wellbeing, such globalization and tribalization should be avoided.

\subsection{Internationalization and the Internationalized Interdependent Community}

The alternative to globalization and tribalization is internationalization. Ac- 
cording to Herman Daly [7] [17], globalization, considered by many to be the inevitable wave of the future, is frequently confused with internationalization, but is in fact something totally different. Globalization refers to global economic integration of many formerly national economies into one global economy, by free trade, especially by free capital mobility, and also, as a distant but increasingly important third, by easy or uncontrolled migration. On the other hand, internationalization refers to the increasing importance of relations between nations: international trade, international treaties, alliances, protocols, etc. The basic unit of community and policy remains the nation, even as relations among nations, and among individuals in different nations, become increasingly necessary and important, so the nations are interdependent in the highly industrial society. The result of internationalization is "the internationalized interdependent community" based on rule of interdependence among different civilizations and nations.

Tribalization has rigid boundary, unilateral international relation, independent economy-politics, and tribe as basic unit. The result of tribalization is territorial rational civilization. Globalization has open boundary, globalized international relation, integrated economy-politics, and the globe as basic unit. Globalization brings about the globalized community. Internationalization is the middle way between globalization and tribalization. Internationalization has varied boundary, multilateral international relation, interdependent economy-politics, and nation as basic unit. The three local civilizations and the two world communities are shown in Table 5 and in Figure 1.

\subsection{The Factors in the Interdependent Coexistence of the Rational Civilizations}

The current highly international interdependence produces the purposed internationalized interdependent community which allows the interdependent coexistence of the three rational civilizations. The important factors in the interdependent coexistence include the promotion of rational civilizations, the basic

Table 5. Three civilizations and two communities.

\begin{tabular}{|c|c|c|c|c|c|c|}
\hline $\begin{array}{l}\text { Civilization/ } \\
\text { community }\end{array}$ & Worldview & Boundary & $\begin{array}{c}\text { Basic } \\
\text { human nature }\end{array}$ & Rule of & Democracy & Origin \\
\hline $\begin{array}{l}\text { Territory rational } \\
\text { civilization }\end{array}$ & Territorial & Rigid & $\begin{array}{l}\text { Good ingroup and } \\
\text { bad outgroup }\end{array}$ & boundary & Nationalist & $\begin{array}{c}\text { Tribes before } \\
\text { Axial Age }\end{array}$ \\
\hline $\begin{array}{l}\text { Discrete rational } \\
\text { civilization }\end{array}$ & Discrete & Flexible & $\begin{array}{c}\text { Discrete } \\
\text { bad individuals }\end{array}$ & law & Liberty-equality & $\begin{array}{c}\text { Middle East and } \\
\text { Grace in Axial Age }\end{array}$ \\
\hline $\begin{array}{c}\text { Connective } \\
\text { rational civilization }\end{array}$ & Connective & Flexible & $\begin{array}{c}\text { Connective } \\
\text { good individuals }\end{array}$ & relation & $\begin{array}{l}\text { Common } \\
\text { wellbeing }\end{array}$ & $\begin{array}{l}\text { India and China } \\
\text { in Axial Age }\end{array}$ \\
\hline $\begin{array}{l}\text { Globalized } \\
\text { integrated community }\end{array}$ & Integrated & Open & $\begin{array}{c}\text { Open } \\
\text { individuals }\end{array}$ & integration & None & WB, IMF, WTO \\
\hline $\begin{array}{c}\text { Internationalized } \\
\text { interdependent } \\
\text { community }\end{array}$ & Interdependent & Varied & $\begin{array}{l}\text { Interdependent } \\
\text { individuals }\end{array}$ & interdependence & None & The New Axial Age \\
\hline
\end{tabular}




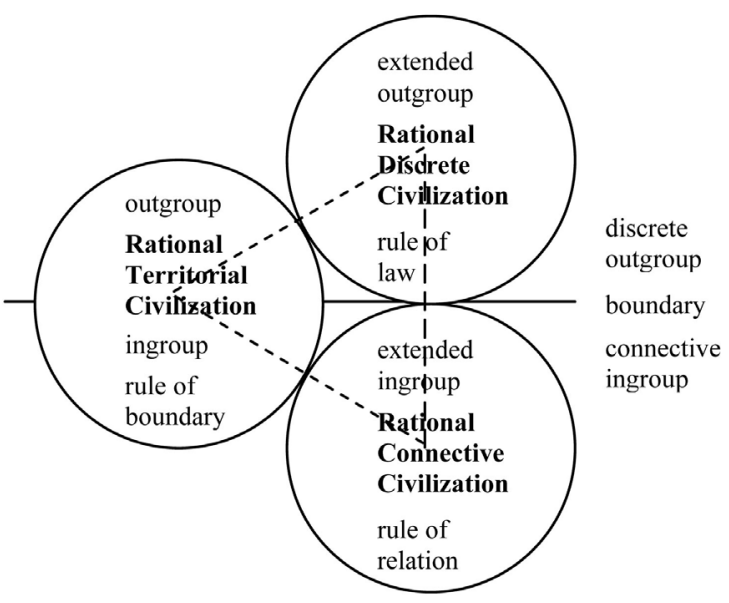

Figure 1. The interdependent co-existence of the three rational civilizations.

rule of relation, the basic rule of law, the potential civilizational boundary, the regional defense boundary, and the cooperation in international relations.

\subsubsection{The Promotion of Rational Civilizations}

The promotion of development of rational civilizations is based on the rational rules including rule of boundary, rule of relation, and rule of law. Such rational rules are derived from rationalism and empiricism. Rationalism is the belief in innate ideas, reason, and deduction, while empiricism is the belief in sense perception, induction, and that there are no innate ideas. Both rationalism and empiricism are derived from the thinking brain with deliberation, precision, and reason.

\subsubsection{The Basic Rule of Relation and the Basic Rule of Law}

The internationalized interdependent community has multilateral rule of relation and rule of law instead of globalized or unilateral rule of relation and rule of law. Multilateral rule of relation provides the basic rule of relation and manner system (civility) for common wellbeing. The basic rule of relation is a community of common origin-destiny for mankind. Scientifically, all people have the common origin. The common origin for mankind provides the base of the international family relation and communication. Empirically, the common destiny for mankind is derived from our highly interdependent industrial community. A community of common destiny is expressed by Chinese government [88]. The common destiny provides the base for international cooperation. Other than the basic rule of relation, different countries have different rules of relation. As a result, internationalization has multilateral rule of relation.

Multilateral rule of law provides the basic rule of law for liberty-equality. The basic rule of law is the rights to life, liberty, and equality for individuals as in the Universal Declaration of Human Rights by the United Nations [89]. Scientifically, all individuals have instincts to life, liberty, and equality. In this internationalized rule of law, all individuals are under the protection of law based on discrete worldview. Other than the basic rule of law, different countries have different 
rules of law. As a result, internationalization has multilateral rule of law.

\subsubsection{The Potential Civilizational Boundary}

The Hofstede's six dimensions of national culture include power distance index (PDI), individualism versus collectivism (IDV), masculinity versus femininity (MAS), uncertainty avoidance index (UAI), long term orientation versus short term normative orientation (LTO), and indulgence versus restraint (IVR) to represent differences among national cultures, and each dimension in each national culture is given a numerical index from the Hofstede's "[Cultures and Organizations: Software of the Mind" (2010) [90]. Power distance index (PDI) expresses the degree to which the less powerful members of a society accept and expect that power is distributed unequally. The fundamental issue here is how a society handles inequalities among people. People in societies exhibiting a large degree of Power Distance accept a hierarchical order in which everybody has a place and which needs no further justification. In societies with low Power Distance, people strive to equalize the distribution of power and demand justification for inequalities of power. The PDI increases with increased distance.

The high side of individualism versus collectivism (IDV), called Individualism, can be defined as a preference for a loosely-knit social framework in which individuals are expected to take care of only themselves and their immediate families. Its opposite, Collectivism, represents a preference for a tightly-knit framework in society in which individuals can expect their relatives or members of a particular ingroup to look after them in exchange for unquestioning loyalty. A society's position on this dimension is reflected in whether people's self-image is defined in terms of "I" or "we". The IDV index increases with increased individualism.

In terms of liberty-equality democracy as discrete civilization, liberty is represented by individualism proportional to the increasing IDV index, while equality is represented by the PDI index proportional to the decreasing PDI. In terms of common wellbeing democracy, common wellbeing is represented by collectivism and the willingness to be united under high authority to keep peace. As a result, the potential democracy type index (PDTI) is expressed by the PDTI formula as follows.

The Potential Democracy Type Index $($ PDTI $)=(100-$ the PDI $)+$ the IDV index

The result of the calculation from 76 cultural units is listed in Table 6. The preference to liberty-equality democracy increases with the increasing potential democracy type index (PDTI), while the preference to common wellbeing democracy increases with the decreasing PDTI. From the PDTI (about 30 points for each group), the five groups are the potential strong liberty-equality democracy, the potential adequate liberty-equality democracy, the potential neutral democracy with equal preference to both democracies, the adequate common wellbeing democracy, and the strong common wellbeing democracy. In Table 5, Arabic-speaking countries include Egypt, Iraq, Kuwait, Lebanon, Libya, Saudi 
Table 6. The civilizational boundary by the democracy type index for the potential democracy type.

\begin{tabular}{|c|c|c|c|c|c|}
\hline Culturalunit & $\begin{array}{c}\text { Potential } \\
\text { Democracy } \\
\text { Type Index }\end{array}$ & Culturalunit & $\begin{array}{c}\text { Potential } \\
\text { Democracy } \\
\text { Type Index }\end{array}$ & Culturalunit & $\begin{array}{c}\text { Potential } \\
\text { Democracy } \\
\text { Type Index }\end{array}$ \\
\hline $\begin{array}{c}\text { Potential Strong } \\
\text { Liberty-Equality } \\
\text { Democracy }\end{array}$ & & $\begin{array}{l}\text { Belgium } \\
\text { (French } \\
\text { speaking) }\end{array}$ & 105 & $\begin{array}{l}\text { Potential } \\
\text { Adequate } \\
\text { Common } \\
\text { Wellbeing } \\
\text { Democracy }\end{array}$ & \\
\hline New Zealand & 157 & France & 103 & Slovenia & 59 \\
\hline Denmark & 156 & Malta & 103 & Taiwan & 59 \\
\hline Great Britain & 154 & Czech Rep. & 101 & Pakistan & 59 \\
\hline Australia & 152 & Argentina & 97 & $\begin{array}{c}\text { Arabic } \\
\text { speaking Arab }\end{array}$ & 58 \\
\hline United States & 151 & $\begin{array}{l}\text { Switzerland } \\
\text { (French) }\end{array}$ & 94 & South Korea & 58 \\
\hline Austria & 144 & Spain & 94 & Hong Kong & 57 \\
\hline $\begin{array}{l}\text { Switzerland } \\
\text { (German) }\end{array}$ & 143 & Jamaica & 94 & Thailand & 56 \\
\hline Netherlands & 142 & Poland & 92 & El Salvador & 53 \\
\hline Ireland & 142 & Japan & 92 & Peru & 52 \\
\hline Canada (total) & 141 & & & Vietnam & 50 \\
\hline Israel & 141 & $\begin{array}{c}\text { Potential } \\
\text { Neutral } \\
\text { Democracy }\end{array}$ & & Mexico & 49 \\
\hline Sweden & 140 & Iran & 83 & Slovakia & 48 \\
\hline Norway & 138 & Costa Rica & 80 & Russia & 46 \\
\hline Hungary & 134 & Morocco & 76 & Singapore & 46 \\
\hline Germany & 132 & Uruguay & 75 & Colombia & 46 \\
\hline Finland & 130 & Greece & 75 & Africa West & 43 \\
\hline Italy & 126 & India & 71 & Romania & 40 \\
\hline Latvia & 126 & Turkey & 71 & Bangladesh & 40 \\
\hline Estonia & 120 & Brazil & 69 & China & 40 \\
\hline Luxembourg & 120 & $\begin{array}{l}\text { Trinidad } \\
\text { Portugal }\end{array}$ & $\begin{array}{l}69 \\
64\end{array}$ & $\begin{array}{c}\text { Serbia } \\
\text { Philippines }\end{array}$ & $\begin{array}{l}39 \\
38\end{array}$ \\
\hline $\begin{array}{c}\text { Potential } \\
\text { Adequate } \\
\text { Liberty-Equality } \\
\text { Democracy }\end{array}$ & & Africa East & 63 & Indonesia & 36 \\
\hline Canada (Quebec) & 119 & Suriname & 62 & Venezuela & 31 \\
\hline Lithuania & 118 & Croatia & 60 & Ecuador & 30 \\
\hline $\begin{array}{c}\text { Belgium } \\
\text { (Dutch speaking) }\end{array}$ & 117 & Bulgaria & 60 & & \\
\hline
\end{tabular}




\section{Continued}

\begin{tabular}{cccc}
\hline & & Potential & \\
S Africa (white) & & Strong & \\
& & Common & \\
& & Wellbeing & \\
& & Democracy & \\
& & Malaysia & 22 \\
& & Panama & 16 \\
& & Guatemala & 11 \\
\hline
\end{tabular}

Arabia, and United Arab Emirates, East Africa includes Ethiopia, Kenya, Tanzania, and Zambia, and West Africa includes Ghana, Nigeria, and Sierra Leone.

The results of the potential democracy types show that in terms of Christian culture, Protestant Christian culture prefers mostly potential strong liberty-equality democracy, Catholic Christian culture prefers mostly potential adequate liberty-equality democracy, potential neutral democracy, and potential adequate common wellbeing democracy, and Eastern Orthodox Christian culture mostly prefers potential neutral democracy and potential adequate common wellbeing democracy. Israel prefers potential strong liberty-equality democracy because of its strong egalitarianism culture. In Asia, only Japan barely prefers potential adequate liberty-equality democracy because of its active westernization since 1868 (The Meiji Restoration). All other countries with Confucian culture prefer potential adequate common wellbeing democracy. India prefers potential neutral democracy, and all other countries with Indian culture prefer mostly potential adequate common wellbeing democracy. Only Iran and Turkey prefer potential neutral democracy, and all other countries with Muslim culture prefer mostly adequate common wellbeing democracy.

The actual democracies in many Western countries follow the potential democracies by the PDTI with some exceptions. As a result, the PDTI can be considered as a way establishes the civilizational boundary. After the Cold War, under the domination of liberty-equality democracy, almost all countries with potential liberty-equality democracy have become the countries with actual liberty-equality democracy. However, many countries with potential common wellbeing democracy in Asia, East Europe, Africa, and Central-South America practice liberty-equality democracy with multiple political parties. These countries have misplaced democracy. Without sufficient individualism and egalitarianism to form discrete and independent individuals, people are loyal to their tribe-party, resulting in bitter and chaotic tribal-party wars against one another. Without sufficient individualism and egalitarianism, liberty-equality democracy becomes chaotic tribalization. The result is chaotic politics. The remedy to the countries with such chaotic misplaced democracy is orderly common wellbeing democracy (collectivism-meritocracy democracy) enforced by natural rule of relation with adequate unnatural rule of law for basic individual right-wellbeing, anti-corruption, anti-dictatorship, and free market. Common wellbeing democracy 
is operated under one political party under sufficient collectivism and meritocracy to run an ethical professional government for the common wellbeing of all people.

The civilizational boundary derived from the PDTI can be a framework for cross-civilizational communication. Cross-cultural communication requires being aware of civilizational differences because what may be considered perfectly acceptable and natural in one country, can be confusing or even offensive in another. Because of the difference in worldview, discrete rational civilization has more individual right-wellbeing and less collective right-wellbeing than the connective rational civilization. The discrete rational civilization has less tolerance of individual disturbance and more tolerance of collective disturbance than the connective rational civilization. The understanding that different civilizations have different preferences and tolerances improves the mutual understanding and communication between different civilizations. In this way of mutual understanding, one does not become an arrogant hypocrite as described by Jesus, "You hypocrite, first take the plank out of your own eye, and then you will see clearly to remove the speck from your brother's eye" (Matthew 7: 5). The national and civilizational boundaries must be respected. There is no hegemonic nation and civilization in the internationalized interdependent community. In interdependent coexistence, the difference between them actually can help each other to minimize excessive individual or collective right-wellbeing. In this way, discrete civilization and connective civilization are interdependent. Both civilizations have the basic rule of relation and rule of law. This interdependent coexistence of discrete and connective civilization is like the symbol of interdependent yin-yang in Figure 2. Yin has small yang at its core, yang has small yin at its core, and yin and yang are in balance with each other. Yin does not dominate yang, and yang does not dominate yin. The political interdependent coexistence of discrete liberty-equality democracy for individual right-wellbeing and connective common wellbeing democracy for collective right-wellbeing allows the minimization of excessive individual or collective right-wellbeing.

Different civilizations produce different economies and science-engineering. The economy in discrete rational civilization is better in quality (advanced technology) and worse in quantity (production) than the economy in connective

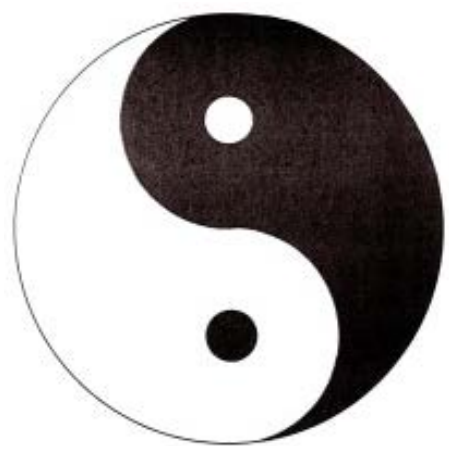

Figure 2. Yin-yang symbol. 
rational economy, because the economy in discrete rational civilization is more innovative and less coordinated than the economy in connective rational civilization. Similarly, discrete rational civilization is better academically in science and worse in engineering than connective rational civilization as shown in Best Global Universities Rankings by US News \& World Report [91]. The international economy can actually take the advantage of such interdependent strengths in economy and science-engineering. The economic interdependent coexistence of discrete civilization for tremendous technological and scientific advancement and connective civilization for phenomenal poverty reduction and industrial production improves global economy.

Most countries use mixed economy which blends planned economy with free market, and mixes state owned enterprise (SOE) with private owned enterprise (POE) [92]. In general, without enough capital and expertise in the private sector, developing countries use planned economy and SOE to start economy. With enough capital and expertise in the private sector, developed countries use free market and POE which are much more efficient than planned economy and SOE [93]. In China, POE now accounts for $2 / 3$ of the economy and $90 \%$ of the export. As a result, it is natural for a developing country to increase the portions of efficient free market and efficient POE as the economy becomes mature. Eventually, all countries will have similar mixed economy adaptable to well-developed economy.

Globalization and automation inevitably increase the wealth gap between the rich and the poor. The gap between the rich and the poor can be in the same location or between urban area and rural area and among different areas in the same country. Different countries have different ways to narrow such gap. In discrete civilization based on discrete worldview where individuals are discrete, the way to narrow such gap is from progressive tax and social welfare programs without significant direct involvement from government. In connective civilization based on connective worldview where individuals are connected, the way to narrow such gap involves significant direct involvement from government. In China, the poverty alleviation strategy for poor rural area follows a five-batch policy based on industrial development, relocation, eco-compensation, education, and social security. Discrete civilization is unlikely to follow such poverty alleviation strategy.

All major religions are rational, and have the common mental origin. In this highly interdependent international community, all major religions have the common destiny that is to build the harmonious international community on earth as in heaven to provide interdependent coexistence of religions as well as rule of religious moral relation and rule of religious-moral law.

\subsubsection{The Regional Defense Boundary}

The interdependent coexistence of territorial rational civilization and discrete-connective civilization regulates the people flow (immigration) and capital flow (investment) across national boundaries to prevent disruptions in politics 
and economy. The defense interdependent coexistence with territorial civilization based on rule of boundary provides the regional defense boundary based on rule of boundary from the "Monroe Doctrine" to prevent the outside military intervention from hegemons [94]. Every country in the world belongs to an international regional defense community in the "International Regional Defense Community Organization" (the IRDCO). The common identities of a regional community include some or all of the shared geography region, shared existing regional international organization, shared dominant cultural-religion, shard dominant language, shared dominant intragroup relation, and shared dominant worldview. Each regional community has at least one economically strong country for its protection and strength. The 12 communities in the International Regional Defense Community Organization (IRDCO) with 195 states [95] are as follows and in Table 7.

The North American Community

Canada, Mexico, the USA.

The South American Community

Antigua and Barbuda, Argentina, Bahamas, Barbados, Belize, Bolivia, Brazil, Chile, Colombia, Costa Rica, Cuba, Dominica, Dominican Republic, Ecuador, El Salvador, Grenada, Guatemala, Guyana, Haiti, Honduras, Jamaica, Nicaragua, Panama, Paraguay, Peru, Saint Kitts and Nevis, Saint Lucia, Saint Vincent and The Grenadines, Suriname, Trinidad and Tobago, Uruguay, Venezuela.

Table 7. The international regional defense community organization (IRDCO).

\begin{tabular}{|c|c|c|c|c|}
\hline $\begin{array}{c}\text { Regional } \\
\text { community }\end{array}$ & $\begin{array}{l}\text { Major } \\
\text { country }\end{array}$ & $\begin{array}{c}\text { Major existing } \\
\text { organization }\end{array}$ & $\begin{array}{c}\text { Major } \\
\text { cultural-religious } \\
\text { influence }\end{array}$ & $\begin{array}{c}\text { Major } \\
\text { languages }\end{array}$ \\
\hline North American & USA & NAFTA & Christianity & English-Spanish \\
\hline South American & Brazil & OAS & Christianity & Spanish-Portuguese \\
\hline East Asian & China & & Confucianism & Mixed languages \\
\hline South Asian & India & ASEAN & Indian culture & Mixed language \\
\hline Midwest Asian & Turkey & & Islam & Mixed language \\
\hline Southwest Asian & Saudi Arabia & Arab League & Islam & Arabic \\
\hline Eurasian & Russia & EAEU & Christianity-Islam & Russian \\
\hline West European & Germany-France & EU & Christianity & Mixed language \\
\hline North African & Egypt & $\begin{array}{c}\text { Arab League, } \\
\text { ECOWAS }\end{array}$ & Islam & Mixed language \\
\hline West African & Nigeria & $\begin{array}{c}\text { ECOWAS and } \\
\text { ECCAS }\end{array}$ & Christianity & Mixed language \\
\hline East-South African & South Africa & $\begin{array}{c}\text { COMESA, EAC, } \\
\text { and SADC }\end{array}$ & Christianity & Mixed language \\
\hline $\begin{array}{l}\text { Pacific Islands } \\
\text { Forum }\end{array}$ & Australia & $\begin{array}{l}\text { Pacific Islands } \\
\text { Forum } \\
\text { Community }\end{array}$ & Christianity & English \\
\hline
\end{tabular}




\section{The East Asian Community}

China, Japan, Mongolia, Philippines, The Republic of Korea, the Democratic People's Republic of Korea, Viet Nam.

The South Asian Community

Bangladesh, Bhutan, Brunei, Cambodia, Laos, Malaysia, Singapore, India, Indonesia, Maldives, Myanmar, Nepal, Sri Lanka, Thailand, Timor-Leste.

The Midwest Asian Community

Afghanistan, Iran, Iraq, Pakistan, Syria, Turkey.

The Southwest Asian Community

Bahrain, Israel, Jordan, Lebanon, Kuwait, Oman, Palestine, Qatar, Saudi Arabia, The United Arab Emirates, Yemen.

The Eurasian Community

Armenia, Azerbaijan, Belarus, Georgia, Kazakhstan, Kyrgyzstan, Russia, Tajikistan, Turkmenistan, Uzbekistan.

The West European Community

Albania, Andorra, Austria, Belgium, Bosnia and Herzegovina, Bulgaria, Croatia, Cyprus, Czech Republic, Denmark, Estonia, Finland, France, Germany, Greece, Hungary, Iceland, Ireland, Italy, Latvia, Liechtenstein, Lithuania, Luxembourg, Malta, Moldova, Monaco, Montenegro, Netherlands, North Macedonia, Norway, Poland, Portugal, Romania, San Marino, Serbia, Slovakia, Slovenia, Spain, Sweden, Switzerland, Ukraine, the United Kingdom, Vatican City.

The North African Community

Algeria, Comoros, Burkina Faso, Djibouti, Egypt, Gambia, Guinea, GuineaBissau, Libya, Mali, Mauritania, Morocco, Niger, Senegal, Sierra Leone, Somalia, Sudan, Tunisia.

The West African Community

Benin, Cape Verde, Cameroon, Central African Republic, Chad, Côte d'Ivoire, Democratic Republic of the Congo, Equatorial Guinea, Gabon, Ghana, Liberia, Nigeria, Republic of the Congo, São Tomé and Príncipe, Togo.

The East-South African Community

Angola, Botswana, Burundi, Eritrea, Eswatini, Ethiopia, Kenya, Lesotho. Madagascar, Malawi. Mauritius, Mozambique, Namibia, Rwanda, Seychelles, South Africa, South Sudan, Tanzania, Uganda, Zambia, Zimbabwe.

Pacific Islands Forum Community

Australia, Fiji, Kiribati, Marshall Islands, Micronesia, Nauru, New Zealand, Palau, Papua New Guinea, Samoa, Solomon Islands, Tonga, Tuvalu, Vanuatu.

Five (Brazil, Russia, India, China, and South Africa) of the twelve major countries in the IRDCO are in BRICS which is a major international community. With the territorial regional protective boundary, each regional community enforces the "Monroe Doctrine" that forbids military intrusion from the countries outside of a regional community except the intervention approved by the United Nations. As a result, all overseas military bases as the military intrusion from the countries outside of a regional community have to be abolished. All defense treaties connected to the countries outside of a regional community also 
have to be ended. The regional communities which are for military defense allow individual nations to maintain all international economic treaties inside and outside of the communities. Different regional communities will have different degrees of economic cooperation within the communities.

The study design, sample size and references of relative studies for the civilization boundary and the regional defense boundary are summarized in Table 8 .

\subsubsection{The Cooperation in the International Relations}

The interdependent coexistence of the international orders can provide peace and prosperity. The boundary international order provides the regional defense boundary for the International Regional Defense Community Organization (IRDCO). The liberal economic international order enhances global economic growth from the WB, IMF, and WTO. The socialist economic-environmental international order protects human welfare and environment for the present and future humans. The common wellbeing international order produces the community of common destiny, enhances international trade, and minimizes the large scale migration of people from poor nations to rich nations. The United Nations is the platform for all nations to resolve international problems.

\subsection{The New Axial Age}

The mega empires before and during the Axial Age unified many tribes within the mega empires, so the old tribal boundary became flexible. To deal with flexible tribal boundary in the mega empires, the great rational thinkers in the Axial Age produces the discrete Western rational civilization originated in Middle East and Greece and the connective Eastern rational civilization originated in India and China to replace the tribal territorial civilization originated from the tribes before the Axial Age. Before the Industrial Revolution, the contact between the discrete Western rational civilization and the connective Eastern rational civilization was limited due to geographic distance and barrier, so the civilizational boundary was rigid. The increasing development in the Industrial Revolution increases the contact among civilizations. Now the Fourth Industrial Revolution [83] brings about the flexible civilizational boundary as indicated by "The Clash of Civilizations and the Remaking of World Order" by political scientist Samuel Huntington [3]. To deal with flexible civilizational boundary brings about the

Table 8 . The civilizational boundary and the regional defense boundary.

\begin{tabular}{|c|c|c|c|}
\hline Study & Study design & Sample size & Reference \\
\hline $\begin{array}{l}\text { Civilizational } \\
\text { boundary }\end{array}$ & $\begin{array}{l}\text { The civilizational boundary } \\
\text { study based on the PDI and } \\
\text { the IDV in the Hofstede } \\
\text { model for national culture }\end{array}$ & 76 cultural units & $\begin{array}{l}\text { Hofstede, G. et al. (2010) } \\
\text { Cultures and } \\
\text { Organizations: } \\
\text { Software of the Mind }\end{array}$ \\
\hline $\begin{array}{l}\text { Regional } \\
\text { defense } \\
\text { boundary }\end{array}$ & $\begin{array}{l}\text { The regional defense } \\
\text { boundary based on the } \\
\text { United Nations members and } \\
\text { their locations and cultures }\end{array}$ & 195 states & $\begin{array}{c}\text { The United Nations (2019) } \\
\text { Member States }\end{array}$ \\
\hline
\end{tabular}


collective rational thinking from people in the New Axial Age. Each generation has the responsibility to provide the improved future for the future generations. The improved future from the collective rational thinking in the New Axial Age to deal with the new international community of the flexible civilizational boundary will last for a long time.

\section{Summary}

The paper purposes that the mental origin of the rational civilization consists of the social brain for instinctive intragroup relations and worldviews to form the original human social group, the mental immune system for instinctive mental therapy, theory of imaginary mind for imaginary religious and political entities with their own minds to form cohesive large social groups, and the thinking brain for rule to form rational civilization. The principles for intragroup relations are commitment for family, reciprocity for alliance, interdependence for division of labor, and generativity for multigeneration. Worldviews as intergroup relations include territory worldview with rigid boundary between ingroup and outgroup, discrete worldview with flexible boundary for extended outgroup and connective worldview with flexible boundary for extended ingroup. In discrete worldview, individuals are discrete and independent as extended outgroup, while in connective worldview, individuals are connective and related as extended ingroup.

All supernatural entities and large social groups entities such as nation-states are derived from theory of imaginary mind where a person attributes mental states of mind (beliefs, intents, desires, emotions, knowledge, etc.) to imaginary others (supernatural deities and nation-states), and understands that imaginary others have beliefs, desires, intentions, and perspectives that are different from the person. Theory of imaginary mind is derived from theory of real mind as the original theory of mind where a person attributes mental state of mind to the others as real people, instead of imaginary entities. The thinking brain brings about rational rules (rule of boundary, rule of law, and rule of relation).

The first rational civilization is territorial tribal rational civilization originated from the tribes before the Axial Age. Afterward, the two rational civilizations are the discrete Western rational civilization originated from the mega empires in Middle East and Greece during the Axial Age, and the connective Eastern rational civilization originated from the mega empires in India and China during the Axial Age. The mega empires before and during the Axial Age unified many tribes within the mega empires, so the old tribal boundary became flexible. To deal with flexible tribal boundary in the mega empires, the great rational thinkers in the Axial Age produces discrete Western rational civilization the connective Eastern rational civilization to replace the tribal territorial civilization before the Axial Age. Territorial rational civilization with territorial worldview for ingroup and outgroup individuals is based on rule of boundary to deal with basically good ingroup individuals and basically bad outgroup individuals. Discrete 
Western rational civilization with discrete worldview for discrete and independent individuals is based on rule of law to deal with basically discrete bad individuals. Connective Eastern rational civilization with connective worldview for connective and related individuals is based on rule of relation to deal with basically connective good individuals. All major religions are derived from the mega empires based on discrete or connective civilization. The fall of mega empires produced territorial rational civilization within discrete or connective civilization maintained by the major religions based on discrete or connective civilization.

The much improved living standard and education for individuals in the Industrial Revolution bring about democracies, including territorial nationalist democracy (tribalism democracy) based on rule of boundary from territorial rational civilization, discrete liberty-equality democracy (individualism-egalitarianism Democracy) based on rule of law from discrete rational civilization, and connective common wellbeing democracy (collectivism-meritocracy democracy) based on rule of relation from connective rational civilization.

Before the Industrial Revolution, the civilizational boundary between the East and the West was rigid with very limited contact between the two civilizations. The civilizational boundary has become flexible as indicated by "The Clash of Civilizations and the Remaking of World Order" by political scientist Samuel Huntington [3], and the economy has become interdependent. The result is the international interdependence with flexible civilizational boundary. The two possible communities from the international interdependence are the globalized integrated community and the internationalized interdependent community. The globalized integrated community from the WB, IMF, and WTO based on rule of integration integrates all civilizations into basically discrete Western rational civilization with globe as the basic unit. The current international situation indicates that the futile globalized integrated community as shown by Sociologist Koert Debeuf in "Tribalization: Why war is coming" [16], which describes that the end of globalization is tribalization which brings chaos and poverty. The alternative is the internationalized interdependent community proposed by Herman Daly [7] [17]. The internationalized interdependent community based on rule of interdependence brings about the independent coexistences of the rational civilization with nation as basic unit. The important factors in rule of interdependence in the internationalized interdependent community include the promotion of rational civilizations, the basic rule of relation of common origin-destiny for mankind, the basic rule of law the Universal Declaration of Human Rights by the United Nations, the potential civilizational boundary from the Hofstede model for national culture, the regional defense boundary based on the Monroe Doctrine, and the cooperation in international relations.

To deal with flexible civilizational boundary brings about the collective rational thinking from people in the New Axial Age. Each generation has the responsibility to provide the improved future for the future generations. The improved future from the collective rational thinking in the New Axial Age to deal 
with the new international community of the flexible civilizational boundary will last for a long time.

\section{Conflicts of Interest}

The author declares no conflicts of interest regarding the publication of this paper.

\section{References}

[1] Naipaul, V. (1990) Our Universal Civilization. New York Times, November 5.

[2] Naipaul, V. (2014) Our Universal Civilization. South China Sea Press, Haikou, China.

[3] Huntington, S. (1996) The Clash of Civilizations and the Remaking of World Order. Simon \& Schuster, New York.

[4] Fukuyama, F. (1992) The End of History and the Last Man. Free Press, New York.

[5] Babones, S. (2017) American Tianxia: Chinese Money, American Power, and the End of History. Policy Press, Bristol. https://doi.org/10.1332/policypress/9781447336808.001.0001

[6] Tallman, S. and Fladmoe-Lindquist, K. (2002) Internationalization, Globalization, and Capability-Based Strategy. California Management Review, 45, 116-135. https://doi.org/10.2307/41166156

[7] Daly, H. (1999) Globalization versus Internationalization-Some Implications. Ecological Economics, 31, 31-37.

[8] Bhagwati, J. (2007) In Defense of Globalization. Oxford University Press, Oxford.

[9] The Economist Intelligence Unit (2019) Democracy Index 2018: Me Too? https://www.eiu.com/Handlers/WhitepaperHandler.ashx?fi=Democracy_Index_201 8.pdf\&mode $=$ wp\&campaignid=Democracy 2018

[10] Nisbett, R. and Masuda, T. (2003) Culture and Point of View. Proceedings of the National Academy of Sciences, 100, 11163-11170. https://doi.org/10.1073/pnas.1934527100

[11] Shih, H. (1919) An Outline of the History of Chinese Philosophy. Commercial Press, Shanghai.

[12] Munro, D. (1985) Individualism and Holism: Studies in Confucian and Taoist Values. Center for Chinese Studies, University of Michigan, Ann Arbor.

[13] Nisbett, R. (2004) The Geography of Thought: How Asians and Westerners Think Differently... and Why. Free Press, New York.

[14] Yuki, M., et al. (2005) Cross-Cultural Differences in Relationship- and Group-Based Trust. Personality and Social Psychology Bulletin, 31, 48-62. https://doi.org/10.1177/0146167204271305

[15] Joas, H. and Bellah, R. (2012) The Axial Age and Its Consequences. Harvard University Press, Cambridge. https://doi.org/10.4159/harvard.9780674067400

[16] Debeuf, K. (2019) Tribalization: Why War Is Coming. Academic \& Scientific Publishers, Bruxelles.

[17] Herman Daly (2017) Trump's Growthism: Its Roots in Neoclassical Economic Theory. Real-World Economics Review, 78, 86-97.

[18] Ferguson, N. (2008) Team “Chimerica”. The Washington Post, November 17, 2008. 
[19] Dunbar, R. (2009) The Social Brain Hypothesis and Its Implications for Social Evolution. Annals of Human Biology, 36, 562-572. https://doi.org/10.1080/03014460902960289

[20] Dunbar, R. (2016) The Social Brain Hypothesis and Human Evolution. Oxford Research Encyclopedia of Psychology. https://doi.org/10.1093/acrefore/9780190236557.013.44

[21] Frith, C. (2007) The Social Brain? Philosophical Transactions of the Royal Society B: Biological Sciences, 362, 671-678. https://doi.org/10.1098/rstb.2006.2003

[22] Cozolino, L. (2006) The Neuroscience of Human Relationships: Attachment and the Developing Social Brain. W. W. Norton \& Co., New York.

[23] Chung, D. (2018) The Mental Protection System for Protective Behaviors: The Social Brain and the Mental Immune System. Journal of Behavioral and Brain Science, 8, 31-55. https://doi.org/10.4236/jbbs.2018.81003

[24] Hamilton, W. (1964) The Genetical Evolution of Social Behavior II. Journal of Theoretical Biology, 7, 17-52. https://doi.org/10.1016/0022-5193(64)90039-6

[25] Shultz, S. and Dunbar, R. (2007) The Evolution of the Social Brain: Anthropoid Primates Contrast with Other Vertebrates. Proceeding of Royal Society B, 274, 2429-2436. https://doi.org/10.1098/rspb.2007.0693

[26] Dunbar, R. (1993) Coevolution of Neocortex Size, Group Size and Language in Humans. Behavioral and Brain Sciences, 16, 681-735. https://doi.org/10.1017/S0140525X00032325

[27] Wilson, E.O. (2012) The Social Conquest of the Earth. W. W. Norton \& Company, New York.

[28] Chung, D. (2016) The Basic Principles of Family Intragroup Relation and Euintragroup Relation: Human Evolution. Natural Science, 8, 8-19. https://doi.org/10.4236/ns.2016.81002

[29] Crespi, B.J. and Douglas, Y. (1995) The Definition of Eusociality. Behavior Ecology, 6, 109-115. https://doi.org/10.1093/beheco/6.1.109

[30] Fonagy, P., Gergely, G., Jurist, E. and Target, M. (2002) Affect Regulation, Mentalization and the Development of the Self. Other Press, New York.

[31] Erikson, E. and Erikson, J. (1998) The Life Cycle Completed. W. W. Norton \& Company, New York.

[32] Slater, C.L. (2003) Generativity versus Stagnation: An Elaboration of Erikson's Adult Stage of Human Development. Journal of Adult Development, 10, 53-65. https://doi.org/10.1023/A:1020790820868

[33] McAdams, D. and De St. Aubin, E. (1992) A Theory of Generativity and Its Assessment through Self-Report, Behavioral Acts, and Narrative Themes in Autobiography. Journal of Personality and Social Psychology, 62, 1003-1015. https://doi.org/10.1037/0022-3514.62.6.1003

[34] Chung, D.Y. (2018) The Eight Stages of Psychosocial Protective Development: Developmental Psychology. Journal of Behavioral and Brain Science, 8, 369-398. https://doi.org/10.4236/jbbs.2018.86024

[35] Turner, J.C. and Reynolds, K.J. (2010) The Story of Social Identity. In: Postmes, T. and Branscombe, N., Eds., Rediscovering Social Identity: Core Sources, Psychology Press, Haikou, China.

[36] Cohen, T., Montoya, R. and Insko, C. (2006) Group Morality and Intergroup Relations: Cross-Cultural and Experimental Evidence. Personality and Social Psychology Bulletin, 32, 1559-1572. https://doi.org/10.1177/0146167206291673 
[37] Shultz, T., Hartshorn, M. and Kaznatcheev, A. (2009) Why Is Ethnocentrism More Common than Humanitarianism? In: Proceedings of the 31 st Annual Conference of the Cognitive Science Society, Cognitive Science Society, Austin, 2010-2015.

[38] Hamlin, J., Mahajan, N. and Wynn, K. (2013) Not Like Me = Bad Infants Prefer Those Who Harm Dissimilar Others. Psychological Science, 24, 589-594. https://doi.org/10.1177/0956797612457785

[39] Wrangham, R. (2018) Two Types of Aggression in Human Evolution. Proceedings of the National Academy of Sciences, 115, 245-2534. https://doi.org/10.1073/pnas.1713611115

[40] Nesdale, D. and Duffy, A. (2011) Social Identity, Peer Group Rejection, and Young Children's Reactive, Displaced, and Proactive Aggression. British Journal of Developmental Psychology, 29, 823-841. https://doi.org/10.1111/j.2044-835X.2010.02012.x

[41] Tulogdi, A., et al. (2010) Brain Mechanisms Involved in Predatory Aggression Are Activated in a Laboratory Model of Violent Intra-Specific Aggression. European Journal of Neuroscience, 32, 1744-1753. https://doi.org/10.1111/j.1460-9568.2010.07429.x

[42] Tulogdi, A., et al. (2015) Neural Mechanisms of Predatory Aggression in RatsImplications for Abnormal Intraspecific Aggression. Behavioural Brain Research, 283, 108-115. https://doi.org/10.1016/j.bbr.2015.01.030

[43] Wilson, M., et al. (2014) Lethal Aggression in Pan Is Better Explained by Adaptive Strategies than Human Impacts. Nature, 513, 414-417. https://doi.org/10.1038/nature13727

[44] McDonald, M. (2012) Evolution and the Psychology of Intergroup Conflict: The Male Warrior Hypothesis. Personality and Social Psychology Bulletin, 32, 1559-1572.

[45] American Psychiatric Association (2013) Diagnostic and Statistical Manual of Mental Disorders. 5th Edition, American Psychiatric Publishing, Arlington. https://doi.org/10.1176/appi.books.9780890425596

[46] Tang, Y., Hölzel, B. and Posner, M. (2015) The Neuroscience of Mindfulness Meditation. Nature Reviews Neuroscience, 16, 213-225. https://doi.org/10.1038/nrn3916

[47] Chung, D. (2016) The Human Religious Evolution. Open Journal of Social Sciences, 4, 75-90. https://doi.org/10.4236/jss.2016.43013

[48] Norenzayan, A., et al. (2016) The Cultural Evolution of Prosocial Religions. Behavioral and Brain Sciences, 39, e1. https://doi.org/10.1017/S0140525X14001356

[49] Shilling, C. and Mellor, P. (1998) Durkheim, Morality and Modernity: Collective Effervescence, Homo Duplex and the Sources of Moral Action. British Journal of Sociology, 49, 193-209. https://doi.org/10.2307/591309

[50] Heyes, C. (2015) Animal Mindreading: What's the Problem? Psychonomic Bulletin \& Review, 22, 313-327. https://doi.org/10.3758/s13423-014-0704-4

[51] Bloch, M. (2006) Why Religion Is Nothing Special But Is Central. Philosophical Transactions of the Royal Society B, 363, 1499. https://doi.org/10.1098/rstb.2008.0007

[52] Calarge, C., Andreasen, N. and O'Leary, D. (2003) Visualizing How One Brain Understands Another: A PET Study of Theory of Mind. American Journal of Psychiatry, 160, 1954-1964. https://doi.org/10.1176/appi.ajp.160.11.1954

[53] Kapogiannis, D., et al. (2014) Brain Networks Shaping Religious Belief. Brain Connectivity, 4, 70-79. https://doi.org/10.1089/brain.2013.0172

[54] Kapogiannis, D., et al. (2009) Cognitive and Neural Foundations of Religious Belief. 
Proceedings of the National Academy of Sciences, 106, 4876-4881. https://doi.org/10.1073/pnas.0811717106

[55] Scott, F. and Baron-Cohen, S. (1996) Imagining Real and Unreal Objects: Evidence of a Dissociation in Autism. Journal of Cognitive Neuroscience, 8, 400-411. https://doi.org/10.1162/jocn.1996.8.4.371

[56] Angus, D., et al. (2015) Limitations in Social Anticipation Are Independent of Imaginative and Theory of Mind Abilities in Children with Autism But Not in Typically Developing Children. Autism, 19, 604-612. https://doi.org/10.1177/1362361314537911

[57] Chan, P., et al. (2016) Theory of Mind Deficit Is Associated with Pretend Play Performance, But Not Playfulness, in Children with Autism Spectrum Disorder. Hong Kong Journal of Occupational Therapy, 28, 43-52. https://doi.org/10.1016/j.hkjot.2016.09.002

[58] Norenzayan, A., Gervais, W. and Trzesniewski, K. (2012) Mentalizing Deficits Constrain Belief in a Personal God. PLoS ONE, 7, e36880. https://doi.org/10.1371/journal.pone.0036880

[59] Taylor, M. (1999) Imaginary Companions and the Children Who Create Them. Oxford University Press, New York.

[60] Taylor, M., et al. (2004) The Characteristics and Correlates of Fantasy in School-Age Children: Imaginary Companions, Impersonation, and Social Understanding. Developmental Psychology, 40, 1173-1187. https://doi.org/10.1037/0012-1649.40.6.1173

[61] Westen, D. (2008) The Political Brain: The Role of Emotion in Deciding the Fate of the Nation. Public Affairs, New York.

[62] Turchin, P. (2008) A Theory for Formation of Large Empires. Journal of Global History, 4, 191-217. https://doi.org/10.1017/S174002280900312X

[63] Muhly, J. (2003) Metalworking/Mining in the Levant. In: Richard, S., Ed., Near Eastern Archaeology, Eisenbrauns, Winona Lake, 5-15.

[64] Nisbett, R., et al. (2001) Culture and Systems of Thought: Holistic versus Analytic Cognition. Psychological Review, 108, 291-310. https://doi.org/10.1037/0033-295X.108.2.291

[65] Talhelm, T., et al. (2014) Large-Scale Psychological Differences within China Explained by Rice versus Wheat Agriculture. Science, 344, 603-608. https://doi.org/10.1126/science.1246850

[66] Emirbayer, M. (1997) Manifesto for a Relational Sociology. The American Journal of Sociology, 103, 281-317. https://doi.org/10.1086/231209

[67] Jiang, G., Lo, T. and Garris, C. (2012) Formation and Trend of Guanxi Practice and Guanxi Phenomenon. International Journal of Criminology and Sociology, 1, 207-220. https://doi.org/10.6000/1929-4409.2012.01.19

[68] Davies, P. (2010) Urban Religion and Rural Religion. In: Stavrakopoulou, F. and Barton, J., Eds., Religious Diversity in Ancient Israel and Judah, Continuum International Publishing Group, New York, 105-117.

[69] Stern, E. (2001) Archaeology of the Land of the Bible, Volume II, the Assvrian. Doubleday, New York.

[70] Nikiprowetzky, V. (1975) Ethical Monotheism. Daedalus, 104, 80-81.

[71] Wunn, I. (2000) Beginning of Religion. Numen, 47, 417-453. https://doi.org/10.1163/156852700511612

[72] Cunliffe, B. (2001) The Oxford Illustrated History of Prehistoric Europe. Oxford 
University Press, Oxford.

[73] Haakonssen, K. (1996) Natural Law and Moral Philosophy: From Grotius to the Scottish Enlightenment. Cambridge University Press, Cambridge. https://doi.org/10.1017/CBO9781139172905

[74] Newar, S. (2016) Dalits of Hinduism: Dharma's Fight for Lost Children. Agniveer, New Delhi.

[75] Grossmann, I. and Kross, E. (2010) The Impact of Culture on Adaptive versus Maladaptive Self-Reflection. Psychological Science, 21, 1150-1157 http://pss.sagepub.com/content/early/2010/07/12/0956797610376655 https://doi.org/10.1177/0956797610376655

[76] Lazar, S., et al. (2005) Meditation Experience Is Associated with Increased Cortical Thickness. Neuroreport, 16, 1893-1897. https://doi.org/10.1097/01.wnr.0000186598.66243.19

[77] Turchin, P. (2006) War and Peace and War: The Rise and Fall of Empires. Plume, New York.

[78] Schwab, K. (2017) The Fourth Industrial Revolution. Crown Publishing Group, New York.

[79] Faust, A. (2013) Early Israel: An Egalitarian Society. Biblical Archaeology Review, 39, 45-49.

[80] Vogel, E. (2011) Deng Xiaoping and the Transformation of China. The Belknap Press of Harvard University Press, Cambridge.

[81] Bell, D. (2015) The China Model: Political Meritocracy and the Limits of Democracy. Princeton University Press, Princeton. https://doi.org/10.1515/9781400865505

[82] The World Bank Group (2018) China: Systematic Country Diagnostic. http://documents.worldbank.org/curated/en/147231519162198351/pdf/China-SCDpublishing-version-final-for-submission-02142018.pdf

[83] The World Bank Group (2011) Poverty Reduction in Vietnam: Achievements and Challenges.

http://documents.worldbank.org/curated/en/870971468318548031/pdf/642790WP0 P107600Box0361535B0PUBLIC0.pdf

[84] Kuo, L. and Kommenda, N. (2018) What Is China's Belt and Road Initiative? The Guardian, London.

[85] Saez, E. (2016) Striking It Richer: The Evolution of Top Incomes in the United States. University of California, Berkeley.

[86] Congressional Budget Office (2016) Trends in Family Wealth, 1989 to 2013. Congressional Budget Office, Washington DC.

[87] Kristof, N. (2014) An Idiot's Guide to Inequality. The New York Times, July 22, 2014.

[88] Zhang, D. (2018) The Concept of "Community of Common Destiny" in China's Diplomacy: Meaning, Motives and Implications. Asia \& the Pacific Policy Studies, 5, 196-207. https://doi.org/10.1002/app5.231

[89] Roosevelt, E., et al. (2001) Universal Declaration of Human Rights. Applewood Book, Bedford.

[90] Hofstede, G., et al (2010) Cultures and Organizations: Software of the Mind. McGraw-Hill, London.

[91] U.S. News \& World Report (2019) Best Global Universities Rankings. U.S. News \& World Report. 
https://www.usnews.com/education/best-global-universities/rankings

[92] Schiller, B. (2010) The Micro Economy Today. McGraw-Hill/Irwin, New York.

[93] Goldeng, E., Grünfeld, L. and Benito, G. (2008) The Performance Differential between Private and State Owned Enterprises: The Roles of Ownership, Management and Market Structure. Journal of Management Studies, 45, 1244-1273. https://doi.org/10.1111/j.1467-6486.2008.00790.x

[94] Chung, D. (2018) Evolutionary Origin of Politics and Political Evolution: Neuropolitics. Journal of Behavioral and Brain Science, 8, 538-561. https://doi.org/10.4236/jbbs.2018.810033

[95] The United Nations (2019) Member States. https://www.un.org/en/member-states 